\title{
Between Max Weber and Gilles Deleuze: Leadership Democracy within a Society of Control
}

By

\author{
Jarryd Aidan Louw
}

A thesis submitted in partial fulfilment of the requirements for the degree of Master of Political Science in the School of History, Philosophy, Political Science, and International Relations.

Victoria University of Wellington

2021 


\section{Acknowledgments}

In the completion of this work, I would like to express my sincere thanks to my advisor, Associate Professor Xavier Marquez, for his invaluable guidance and input concerning both the research and writing of this thesis. Additionally, I would like to thank both the School of History, Philosophy, Political Science and International Relations and Victoria University of Wellington for their resources in completing this work. I would also like to thank my family for their invaluable support while this thesis was undertaken. 


\begin{abstract}
Gilles Deleuze argued that modern western societies are undergoing or have undergone a shift away from a purely disciplinary formation as articulated by Michel Foucault towards new structures of control. Whereas disciplinary societies were defined by the specifics of certain kinds of confinement, what Deleuze terms societies of control emerge from the dissolution of the separation between these forms of confinement and the wider society. Because of this, social control has begun to pervade the individual lives of persons within a society, where persons are treated as subjects from which data and information can be extracted. However, at the same time many modern western societies are also considered or can be classified as what Weber described as leadership democracies, that is, democracies where charismatic leaders are elected and command large followings. Thus, a theoretical question emerges as to how these two theoretical approaches would interact. A society of control by its nature makes the imposition of control over subjects more encompassing while the charismatic leader at the helm of a political apparatus is theoretically able to overcome the various obstacles that impose themselves over most members of a society. The question is how this would include the overcoming of the imposition of the society of control.
\end{abstract}

The purpose of this thesis is to explore how a leadership democracy under the guidance of a charismatic leader, or leaders, is able to overcome the impositions of a society of control. It shall be argued in due course, despite the presence and impositions of a society of control, that such impositions do not impinge upon the nature of the charismatic leader, or leaders, in such a way or to the extent required to prevent the charismatic leader, or leaders, from operating as this kind of leader, or leaders, by definition. In so doing, this thesis explores the manner in which the charismatic leader, or leaders, can overcome the mechanisms of a society of control and maintain the integrity of a leadership democracy in relation to the manner in which societal control is exerted over a population. Given that this thesis deals with a question of pure theory, the nature of this thesis shall be largely formal and shall rely largely on formal argumentation derived from primary and secondary literature as opposed to empirical research, however, where necessary empirical examples and research shall be drawn on for illustration purposes. 


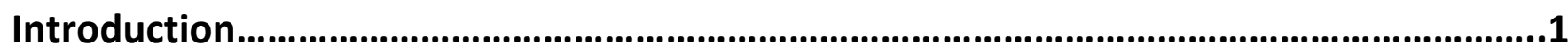

Chapter 1: Outlining Weber's Leadership Democracy............................................................5

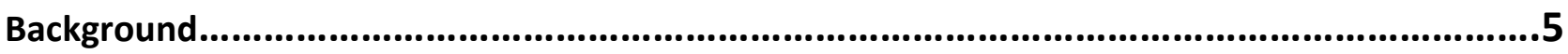

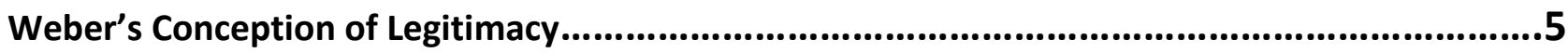

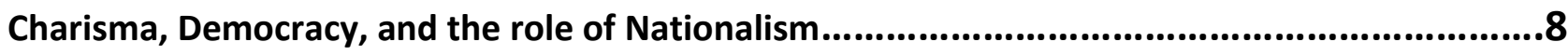

Political Characteristics of Leadership and Political Power Structures..................................10

Chapter 2: Outlining Deleuze's Society of Control................................................................19

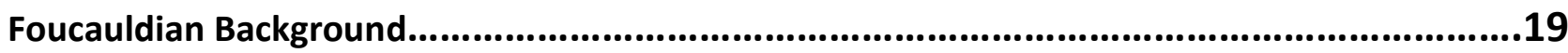

Deleuze's Concept of the Society of Control......................................................................22

Chapter 3: Leadership Democracy within a Society of Control............................................29

The Charismatic Leader, Leadership Democracy, and a Society of Control..............................29

How Can the Charismatic Leader Avoid the Impact of the Society of Control?........................38

The Role of Intrinsic Properties....................................................................42

The Focus on Pure Theory and the Role of Empirical Examples.....................................45

The Nature of the Charismatic Leader's Capabilities in a Society of Control...........................48

Leadership Democracy under a Society of Control...............................................................55

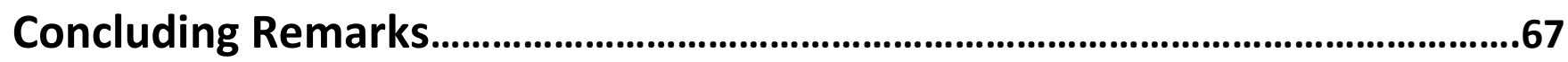

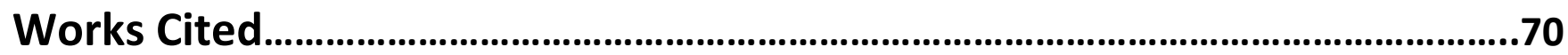




\section{Introduction}

Towards the end of his life, Gilles Deleuze argued that modern western societies are undergoing or have undergone a shift away from a purely disciplinary formation as articulated by Michel Foucault towards new structures of control. ${ }^{1}$ Whereas, disciplinary societies were defined by the specifics of certain kinds of confinement, what Deleuze terms societies of control emerge from the dissolution of the separation between these forms of confinement and the wider society. Because of this social control has begun to pervade the individual lives of persons within a society, persons are treated as subjects from which data and information can be extracted. ${ }^{2}$ However, at the same time, many modern western societies are also considered or can be classified as what Weber described as leadership democracies, that is, democracies where leaders are elected and command large followings. ${ }^{3}$ Thus, a theoretical question emerges as to how these two theoretical approaches would interact. A society of control by its nature makes the imposition of control over subjects more encompassing while the charismatic leader at the helm of a political apparatus is theoretically able to overcome the various obstacles that impose themselves over most members of a society, including the imposition of the society of control.

The purpose of this thesis then is to explore how a leadership democracy under the guidance of a charismatic leader or leaders is able to overcome the impositions of a society of control. It shall be argued in due course in this thesis that despite the presence and imposition of a society of control that a charismatic leader at the helm of a political apparatus can retain their ability to overcome such obstacles. In so doing, this thesis explores the manner in which the charismatic leader or leaders can overcome the mechanisms of a society of control and maintain the functioning of a political apparatus in relation to the manner in which societal control can be exerted over a population. To see how these different aspects would unfold together, and indeed why they are going to be treated together in this thesis and why they

\footnotetext{
${ }^{1}$ Deleuze, Gilles. 1992. "Postscripts on the Society of Control." October 59: 3-7.

${ }^{2}$ Ibid, 3-7.

${ }^{3}$ Weber, Max. 1991. "Bureaucracy." In From Max Weber: Essays In Sociology, by H.H., Mills, C. Wright. (ed.) Gerth, 196-244. London: Routledge; Weber, Max. 1978. "Charisma and its Transformation." In Economy and Society 2, by C. Wittich. G. Roth., 1111-1157. Berkeley: University of California Press; Weber, Max. 1978. "Domination and Legitimacy." In Economy and Society 2, by G. Roth and C. Wittich, 941-955. Berkeley: University of California Press.
} 
are needed for answering the primary research question, they first need to be clarified more in turn.

The first thing to note, as will be explicated in more detail in the thesis proper, is that the charismatic leader or leaders often emerge at the helm of what comes to be known as a leadership democracy, that seeks to place emphasis upon the role of a particular type of individual or individuals at the helm of large-scale political apparatuses. Though these individuals were placed in power via competitive elections, there is also an emphasis upon the dominion by these individuals over the political apparatus and the society over which this apparatus administrates, with the rest of this society also being subject to the mechanisms of the society of control. The second thing to note is that this dominion requires that a certain degree of control be maintained and leveraged over the political apparatuses that must also interact with the mechanism of the society of control. This dominion over the political apparatuses while the society of control is active over the polity places the charismatic leader in an interesting position, in that a question now arises as to how the charismatic leader can escape the influence of the society of control.

This potentiality comes into focus more clearly when one examines the nature of a society of control, which, like the nature of a charismatic leader and a leadership democracy, shall be explicated in more detail in the thesis proper, is taken into consideration. For now, it is sufficient to state that a society of control is based upon the idea that a subject's actions are used as a means of control on the part of various institutional actors. Within this functional description, it needs to be noted that there is also the seeming question of the relationship between the idea of free will as it relates to free acts and theoretical accounts of political phenomena. For the sake of brevity, and due to specific space constraints, this topic of the relationship between accounts of free will and theoretical accounts of political phenomena in and of itself shall not be delved into within this thesis. However, it shall be held, as a background parameter, within the confines of this thesis that such a relationship exists. The reason for such an assumption is that since a society of control seeks to use a subject's actions as a means of control, there is an implied position concerning both free will and volition that seems to accord with the libertarian position on the subject which holds, in basic terms, that an individual is capable of making free choices despite external pressures.

Thereby, another purpose of this thesis, outside of the standard contribution to be made to the general literature of political theory, is to explore an otherwise underexplored aspect of 
the relationship between Weber and Deleuze. Namely, under what specifically modern-day conditions could a charismatic leader at the helm of a leadership democracy overcome the impositions of the society of control and what happens to the idea of a society of control when it is paired with a proper theoretically functional account of institutional political life. Additionally, another motivational purpose of this thesis is to provide a robust example of thinking through the idea of the society of control in the theoretical sense in relation to a set of theoretical ideas that do not ordinarily appear when considering the society of control.

In so doing, this thesis shall draw upon the varied primary and secondary literature concerning Weber's discussions of the nature of leadership democracy and its interaction with the rest of Weber's work. The literature to be drawn upon shall be centred around this interaction and will be used to argue that this idea of a charismatic leader at the helm of a political apparatus or a leadership democracy is not inherently affected by the impacts of a society of control. Additionally, this thesis shall also draw upon both primary and secondary literature concerning Deleuze's exposition of the idea of the society of control and how this idea explicates modern concerns surrounding surveillance. Within the literature, concerning Weber, there is currently no connection to Deleuze and the society of control. Likewise, within the literature pertaining to the society of control, there is currently no work specifically looking at its interaction with either the idea of a charismatic leader or a leadership democracy, rather this literature concerns itself largely with the critique of social formations that exhibit the qualities of the society of control.

This thesis shall be separated into three main sections, outside of this introduction and the concluding remarks. The first section shall provide a theoretical background to Weber. In so doing, this section shall outline the general nature of Weber's theoretical work and will focus upon the idea of leadership democracy within the wider confines of this theoretical work. The second section shall provide a theoretical background to Deleuze. In so doing, this section shall begin with an outline of Foucault, as the Society of Control builds on Foucault's work, namely his theoretical work concerning the idea of a Disciplinary Society. This section also provides an outline of Deleuze's concept of the society of control in general terms and shall also define and explain the concept of a security assemblage as this is the primary mechanism of a society of control. Finally, the third section shall provide a theoretical account of how a charismatic leader at the helm of a political apparatus or leadership democracy is not affected by a society of control. Here it shall be argued that the presence of the society of control does not lead to any imposition upon a charismatic leader or a leadership democracy and that the 
charismatic leader is capable of overcoming and breaking through the constraints imposed by the mechanisms of the society of control. 


\section{Chapter 1: Outlining Weber's Leadership Democracy}

\section{Background}

Weber is often positioned as a liberal thinker within the prevailing German political context of the time. His political focus was on the freedom of the individual within the confines of what is often considered to be a wider liberal nationalist framework embedded within great power politics. ${ }^{4}$ Weber can also be described as a bourgeois middle-class liberal concerning his liberal disposition, a fascinating state of being in its own right when one takes into account that the changes in the social condition taking place during the time of Weber's intellectual output were not particularly amenable to either bourgeois institutions or the liberal values that underpinned them. Indeed, such a state of affairs prompted liberal thinkers to try and find new directions of expression. Given this context, Weber can be seen to be one of those liberal thinkers of fin-de-siècle Europe who sought to rectify the challenges facing liberalism in their own individual and unique ways. ${ }^{5}$ For Weber, the character of liberalism had been and was being, undermined via the creeping bureaucratization taking place in modern society. ${ }^{6}$

\section{Weber's concept of Legitimacy}

Weber's political sociology can be described as pervaded by a blunt political realism. This can be observed in Weber's conception of the State, defined as " $a$ human community that successfully claims the monopoly of the legitimate use of physical force within a given territory", whence it can be observed that Weber does not ascribe to the State any formal moral qualities unlike the case with many other liberal thinkers of the time. ${ }^{7}$ In the same vein, Weber maintained that those who find themselves to be ruled will, due to the inescapable

\footnotetext{
${ }^{4}$ Mommsen, Wolfgang J. 1974. "A Powerful Nation State as Weber's Political Ideal." In Max Weber and German Politics 1890-1920, by Wolfgang J. Mommsen, 35-67. London: University of Chicago Press.

${ }^{5}$ Bellamy, Richard. 1992. Liberalism and Modern Society. University Park: Pennsylvania State University.

${ }^{6}$ Note: Due to the very wide scope of Weber's intellectual output, and the application of that output to this thesis, this section will concern itself purely with a general exposition of his socio-political thought as it applies to political power and will thus omit any specific exposition about its philosophical backdrop beyond the basic observation that it is undergirded by the interplay of Kantianism and Nietzscheanism.

${ }^{7}$ Weber, Max. 1994. "The Profession and Vocation of Politics." In Weber: Political Writings, by Max. Weber, 309-369. Cambridge: Cambridge University Press, p. 312; Kim, Sung Ho. 27. "Max Weber." The Stanford Encyclopedia of Philosophy. November 2017. https://plato.stanford.edu/entries/weber/.
} 
nature of political reality, find themselves to be dominated by those who rule. It is on this basis that for Weber the study of politics is always the study of the different forms through which domination is effectively wielded and maintained, even in cases where an empirical sociology lacking normative content is used. Weber additionally held that any domination that warranted scholarly consideration was constituted by something more than the pure facts concerning suppression and the willingness to obey. Indeed, Weber states that for "the merely external fact of the order being obeyed is not sufficient to signify domination in our sense; we cannot overlook the meaning of the fact that the command is accepted as a valid norm". ${ }^{8}$ Put another way, Weber contended that the domination in question had to be interpreted by both the dominator and dominated in a shared manner, where the ruler makes a claim to legitimacy and those being ruled voluntarily agree to treat that ruler as legitimate. ${ }^{9}$

Starting from this position, Weber subsequently went on to classify three forms of domination based on legitimacy: charismatic legitimacy, traditional legitimacy, and legal-rational legitimacy. Broadly, the claim of charismatic legitimacy relies on the persuasiveness of a particular leader or set of leaders, to convincingly illustrate via word and action their "exceptional sanctity, heroism or exemplary character" in a socio-political setting, whereby if successful the ruler will gain a following from those who are ruled. ${ }^{10}$ Traditional legitimacy relies on a successful claim, that in relation to institutionalized practices, customs, and values, is able to reify a steady form of domination that persists over a long period of time. ${ }^{11}$ In other words, traditional legitimacy emerges from authority being grounded in "the sanctity of ageold rules and power", in which leaders "are designated according to traditional rules and are obeyed because of their traditional status". ${ }^{12}$ Legal rational legitimacy, as opposed to the two former kinds of legitimacy, does not require the primacy of either personality or long spans of time, but rather requires merely observing a set of rules and principles taken to be universal that can only be arrived at via legal norms "established by agreement or by imposition, on grounds of expediency or value-rationality or both"..$^{13}$ It is upon this analysis of legitimacy and

\footnotetext{
${ }^{8}$ Weber, Max. 1978. "Domination and Legitimacy." In Economy and Society 2, by G. Roth and C. Wittich, 941-955. Berkeley: University of California Press, p. 946; Kim, Sung Ho. 27. "Max Weber." The Stanford Encyclopedia of Philosophy. November 2017. https://plato.stanford.edu/entries/weber/. ${ }_{9}^{9}$ Marquez, Xavier. 2016. "The Irrelevance of Legitimacy." Political Studies 64 (1): $19-34$.

${ }^{10}$ Weber, Max. 1994. "Three Types of Legitimate Domination." In Economy and Society 1, by C (ed.) Wittich and G. Roth, 212-301. Berkeley: University of California Press, p. 215.

${ }^{11} \mathrm{Ibid}, \mathrm{pp} .212-301$.

12 Ibid, p. 226.

${ }^{13} \mathrm{lbid}$, p. 217.
} 
the manner in which it is utilized in Weber's political sociology as it relates to domination that Weber is often known. Given Weber's attempt to separate normative content from his political sociology, these ideal types of legitimacy should not be viewed as providing some grounds upon which normative assessment of claims of legitimacy can be made. But Weber's approach to classification has a notable gap as it relates to the conceptual classification of democracy.

On this point, within the Weberian approach, it would seem as though the place of democracy is unstable. Depending on where one is in Weber's work, democracy is at times treated like a fourth form of legitimacy on the basis of its supposed ability to take on legitimacy from below, as opposed to the other three forms of legitimacy which take on legitimacy from above. ${ }^{14}$ While in other areas of Weber's work, democracy is treated as not possessing legitimacy at all and is thus non-legitimate in nature on the basis that it seeks to forge a middle ground between those who are ruled and those who rule. However, without the assumption of hierarchy or asymmetry, Weber's conception of legitimacy goes nowhere. Due to this, Weber was only able to describe the prototypical democracy that arose in communes during the later period of the middle ages within the confines of "revolutionary usurpation" ${ }^{15}$, in which Weber characterized them as the "first deliberately non-legitimate and revolutionary political association". ${ }^{16}$ Because of this, Weber was forced to locate these historical instances of democracy as being outside of his characterization of legitimacy, as being either illegitimate or merely something to which the concept of legitimacy does not apply.

Additionally, Weber utilized another conceptualization of democracy that was based upon the charismatic form of legitimacy. In so doing, Weber used the example of the Puritan sect, where authority finds its legitimacy within a voluntary consenting order of believers who themselves posses' charisma. Because of this, the Puritan sect was able to "insist upon direct democratic administration by the congregation" and in so doing remove the distinction between those who rule and those who are ruled. ${ }^{17}$ Within the confines of a secular context, the vote, as it is utilized within a democracy, becomes the means via which the charisma of

\footnotetext{
${ }^{14}$ Schroeder, Ralph. 1998. Max Weber, Democracy, and Modernization. London: Palgrave Macmilan. ${ }^{15}$ Weber, Max. 1978. "The Occidental City." In Economy and Society 2, by C. Wittich. G. Roth., 12361265. Berkeley: University of California Press, p. 1250.

${ }^{16}$ Weber, Max. 1978. "The Plebeian City." In Economy and Society 2, by C. Wittich. G. Roth., 13011339. Berkeley: University of California Press, p. 1302.

${ }^{17}$ Weber, Max. 1978. "Political and Hierocratic Domination." In Economy and Society 2, by C. Wittich. G. Roth., 1158-1211. Berkeley: University of California Press, p. 1208.
} 
the standard citizen is gathered in the form of the elected representative that in turn becomes "the agent and hence the servant of his voters, not their chosen master". ${ }^{18}$ In this way, democracy becomes a highly specific form of charismatic legitimacy as opposed to being either purely non-legitimate or some kind of the fourth form of domination.

\section{Charisma, Democracy, and the role of Nationalism}

Given what has already been covered, something interesting emerges in Weber's thought as it relates to democracy. Namely, that it would seem that Weber's thought has difficulty in accounting for how democracy has come to be the primary foundation for legitimacy. This difficulty can be seen expressed in Weber's promotion of a leadership democracy after WWI in Germany.

If one grants that the proper self-rule of a people is out of the question as per Weber's political realism, then one is forced to choose between some form of leaderlessness or that of leadership democracy. ${ }^{19}$ For Weber, self-rule was only possible within the confines of rather simple social conditions, in which a "small number of people were equal in status and administrative tasks were simple enough that no" real division between state and community members arose. ${ }^{20}$ Such conditions were theorised as being supposedly prohibited by the existence and functioning of modern social conditions. ${ }^{21}$ Regardless, however, Weber held that democratization had taken place in so far as the older aristocratic social structures had been removed with the creation of the modern state. ${ }^{22}$ In the case of Germany after WWI, Weber conceptualized of a democratic Germany as a form of marketplace where various leaders, all possessing charisma, could be elected into office via the gaining of votes through competition with each other. This component of the competition is of importance because it is through the process of winning this competition that the creation of a leadership that is capable of governing a wide-ranging bureaucracy takes place. In this instance, Weber's focus when it comes to the institutions of a democratic nature has been directed towards the character traits of leadership as opposed to specific democratic principles.

\footnotetext{
${ }^{18}$ Weber, Max. 1978. "Charisma and its Transformation." In Economy and Society 2, by C. Wittich. G. Roth., 1111-1157. Berkeley: University of California Press, p. 1128.

${ }^{19}$ Márquez, Xavier. 2018. "Max Weber's Charismatic Democracy." In Democratic Moments: Reading Democratic Texts, by Xavier. Márquez, 145-152. London: Bloomsbury Academic.

${ }^{20} \mathrm{Ibid}, \mathrm{p} .147$.

${ }^{21}$ Ibid, pp. 145-152.

22 Ibid, pp. 145-152.
} 
However, despite this, it must be noted that Weber's approach to democracy does not rely purely upon certain traits of a leader's personality. Indeed, Weber also contended that politics taking place on a far more local level, as opposed to only within the confines of mass party politics, was also a place from which charismatic leadership qualities arise. Within the confines of this localised environment, when potential leaders are trained to a requisite level of competency, the potential elitism of the Weberian conception of democracy is tempered via the pluralism that arises within this local environment. ${ }^{23}$ Thus, for Weber, civil society has the ability to disperse the qualities of charismatic leadership among the citizenry, and in so doing allows for meaningful democracy to be maintained under charismatic forms of leadership on the condition that political education of leaders takes place within an otherwise pluralistic environment. In other words, charismatic forms of leadership have to be "democratically manufactured" ${ }^{24}$ within a pluralistic civil society with free elections, universal suffrage along with organized political parties.

Weber's focus on the role of civic education was also present in his approach to Nationalism as well. While Weber was fervent in his nationalism, it nevertheless lacked a focus on race, ethnicity, and their supposed primordial qualities, thus setting him apart from the nationalism that was present under Wilhelm's rule of Germany. For instance, during Weber's Freiberg Address of 1895, where his Nationalism was on full display, he made a point of noting that the function of this Nationalism was to act as a way to educate the citizenry in civic matters while also promoting political maturity within the bourgeois class. For Weber, Nationalism was an instrument via which the participation of the citizenry in civic affairs could be increased in a society whose population had started to become more resigned to exclusion from such affairs. ${ }^{25}$

A cornerstone of the attempt to educate the citizenry relied on the exposure of the citizenry to what Weber called the "eternal struggle" in the form of power politics that took place

\footnotetext{
${ }^{23}$ Kim, Sung Ho. 2002. "Max Weber and Civil Society: An Introduction to Max Weber on Voluntary Associational Life (Vereinswesen)." Max Weber Studies 2 (2): 186-98.

${ }^{24}$ Green, Jeffrey Edward. 2008. "Max Weber and the Reinvention of Popular Power." Max Weber Studies 8 (2): 208.

${ }^{25}$ Weber, Max. 1991. "Science as Vocation." In From Max Weber: Essays In Sociology, by H.H., Mills, C. Wright. Gerth, 129-156. London: Routledge.
} 
between nation-states. ${ }^{26}$ In this vein, Weber observed that the exposure of the English citizenry to "the reverberation of a position of world power" and "to 'chronic' political schooling" led to England's ability to build an empire while still maintaining liberal democracy. 27 Thus, the Nationalism of Weber can be articulated as a form of liberal or social imperialism insofar as Weber's thinking is a product of liberalism during the early twentieth-century Europe. ${ }^{28}$ However, despite this, it must be stated that the liberal nationalism of Weber possessed a notable degree of variation from other nationalisms of his day due to its focus on the liberal character of civil education. ${ }^{29}$ Here, Weber held that "nationalistic galvanization would facilitate the breaking of the social bondage imposed on Wilhelmine civil society by incorporating the industrial classes into the public sphere of participatory deliberation" which saw "nationalism as a critical ally of a liberal reform agenda". ${ }^{30}$ Subsequently, the next point of inquiry into Weber's political project concerns the kinds of character qualities needed for effective leadership of both the citizenry and the bureaucracy.

\section{Political Characteristics of Leadership and Political Power Structures}

Two primary ethical virtues, an ethic of responsibility and an ethic of conviction were argued by Weber to be the necessary outcome of a proper education in political matters, despite these two ethics being in tension with each other. Concerning the ethic of responsibility, this holds that the meaning of an action exists as a cause of the effect of that action as it impinges on the external world. The virtue in this ethics concerns the ability to have an objective understanding of the various causal outcomes of the particular action and how one can tailor an action to have the desired outcome. Therefore, ethical questions become a kind of technical question, related in part to carrying out the proper procedure in relation to not only prevailing circumstances but also to free action arrived via the right choice of means with which to carry out the proper procedure. ${ }^{31}$ However, it must be noted at the same time that Weber did not merely conceptualize a standard approach to the relationship between action and intention in the Kantian vein but rather stressed "the causality to which a free agent

\footnotetext{
${ }^{26}$ Weber, Max. 1994. "The Nation State and Economic Policy." In Weber: Political Writings, by Lassman, Peter; Spiers, Ronald., 1-28. Cambridge: Cambridge University Press, p.16.

$27 \mathrm{lbid}$, p. 26.

${ }^{28}$ Beetham, David. 1989. "Max Weber and the Liberal Political Tradition." European Journal of Sociology 30: 311-323.

${ }^{29}$ Kim, Sung Ho. 2007. "Liberalism, Nationalism, and Civil Society." In Max Weber's Politics of Civil Society, by Sung Ho Kim, 133-172. Cambridge: Cambridge University Press.

${ }^{30} \mathrm{Ibid}, \mathrm{p} .147$.

${ }^{31}$ Kim, Sung Ho. 27. "Max Weber." The Stanford Encyclopedia of Philosophy. November 2017. https://plato.stanford.edu/entries/weber/.
} 
subscribes" and in doing so articulates "an ethical integrity between action and consequences". ${ }^{32}$ In this way, Weber's charismatic leader can be described "as someone who keeps calculation in its place" when it comes to evaluating both the consequences of political means and the nature of "responsibility and the world". ${ }^{33}$ Thus, Weber, through an emphasis on the interrelation of freedom and causality, proposes an ethical middle-ground between actions and their consequences, in which one is to respond to the world "as it really is". ${ }^{34}$

Concerning the ethic of conviction, this holds that a free person has the ability to decide on both the means and the ends in an otherwise independent manner: "this concept of personality finds its 'essence' in the constancy of its inner relation to certain ultimate 'values' and 'meanings' of life". ${ }^{35}$ For Weber, the issue here lies in the acknowledgment that the rationality used in deciding on the means cannot be used in deciding on the end, the two forms of reasoning used exist as independent methods of rationality the division between which is reified further by the divisions in values in the modern world. Because of the absence of some objective parameter related to choice, a free person is thus forced to create their own purpose; "ultimately life as a whole, if it is not to be permitted to run on as an event in nature but is instead to be consciously guided, is a series of ultimate decisions through which the soul - as in Plato - chooses its own fate". ${ }^{36}$

Thus, once again, Weber creates a middle way between action and intention founded upon a Kantian conception of integrity in the form of this ethic of conviction. However, the problem here lies in that there seems to be a chasm between these two forms of ethics that does not seem to be easily bridgeable. The requisite concept of a pure integrity that must exit between value and action in a political context, which possesses a deontological nature, does not seem to be reconcilable with the necessary integrity, which possesses a consequentialist nature. However, Weber was nevertheless aware of the separation between these two and this awareness on his part should not be seen to indicate an outright preference for the latter over the former in the context of political education. While Weber was disapproving of the ethic of conviction, he still considered it to have a purpose as a part of "the incalculable

\footnotetext{
${ }^{32}$ Kim, Sung Ho. 27. "Max Weber." The Stanford Encyclopedia of Philosophy. November 2017. https://plato.stanford.edu/entries/weber/.

${ }^{33}$ Satkunanandan, Shalini. 2014. "Max Weber and the Ethos of Politics beyond Calculation." American Political Science Review 108 (1): 169.

${ }^{34}$ Ibid, p. 169.

${ }^{35}$ Weber, Max. 1975. Roscher and Knies: The Logical Problems of Historical Economics. New York: The Free Press, p. 175.

${ }^{36}$ Weber, Max. 1949. The Methodology of the Social Sciences. Chicago: The Free Press, p. 18.
} 
responsibility to respond to the world", in which the association of this ethic with morality provides a space for morality that is much wider than is often noticed. ${ }^{37}$

The opposition between deontology and consequentialism was well understood by Weber, however, he nevertheless held that the two should be merged in some way. "The former recognition lends urgency to the latter agenda". ${ }^{38}$ The resolution of this opposition via the use of "ethical decrees" was of little concern for Weber who sought to discover a moral character that has the capacity to create a synthesis of the two through the force of will alone. ${ }^{39}$ Weber articulated a person possessing this moral character as a "politician with a sense of vocation (Berufspolitiker)" who articulates a combination of passionate conviction with certain ideals as they concern the idea that politics must rationally and calculably serve its realization within the confines of the prevailing condition in the world. ${ }^{40}$ The conclusion of Weber is thus that: "the ethic of conviction and ethic of responsibility are not absolute opposites. They are complementary to one another, and only in the combination do they produce the true human being who is capable of having a 'vocation for politics'". ${ }^{41}$

Thus, Weber's use of ethics as it relates to the analysis of politics does not concern the "formal analysis of moral maxims" and neither does it concern itself with "substantive virtues that reflect some kind of ontic telos". ${ }^{42}$ What Weber is doing here possesses a too high a formalism for it to be classified as some form of Aristotelian virtue ethics while also being too preoccupied with moral character for it to qualify as some form of deontology of a Kantian vein as understood in relatively narrow terms. The primary focus of Weber's ethical project is that it seeks to produce a character that has the capability to unify "conflicting formal virtues to create what he calls "total personality" (Gesamtpersonlichkeit)". 43 This concludes in the form of an "ethical characterology or philosophical anthropology" where the reason and passion are set in proper order via the use of the individual will. In this way, political virtues,

\footnotetext{
${ }^{37}$ Satkunanandan, Shalini. 2014. "Max Weber and the Ethos of Politics beyond Calculation." American Political Science Review 108 (1): 170.

${ }^{38}$ Kim, Sung Ho. 27. "Max Weber." The Stanford Encyclopedia of Philosophy. November 2017. https://plato.stanford.edu/entries/weber/.

${ }^{39}$ Kim, Sung Ho. 27. "Max Weber." The Stanford Encyclopedia of Philosophy. November 2017. https://plato.stanford.edu/entries/weber/.

${ }^{40}$ Weber, Max. 1994. "The Profession and Vocation of Politics." In Weber: Political Writings, by Lassman, Peter; Speirs, Ronald., 309-369. Cambridge: Cambridge University Press, p. 368.

${ }^{41} \mathrm{Ibid}, \mathrm{p} .368$.

${ }^{42}$ Kim, Sung Ho. 27. "Max Weber." The Stanford Encyclopedia of Philosophy. November 2017. https://plato.stanford.edu/entries/weber/.

${ }^{43}$ Ibid.
} 
for Weber, are not located purely within the subjective obligation towards certain values or purely within "detached intellectual integrity, but in their wilful combination in a unified soul". 44

Weber, in line with what has been outlined thus far concerning his approach to politics in general, conceptualised political structures as using force but also held that the method by which this force is to be exercised and the degree to which it is exercised changes in relation to the political organisation to which such force is directed. ${ }^{45}$ These differences in turn impinge upon the outcome of political communities. This is because political structures are not "equally expansive" in that not all political structures seek "outward expansion of their power" in terms of dominating other political territories and political communities in order to either integrate or subordinate them. ${ }^{46}$ Thereby, the nature of political structures could be more isolationist or more expansive on the basis of the power of the internal dynamics between the members of that political structure. ${ }^{47}$

For Weber, it is because of this power that the members of a particular political structure could confer upon themselves a certain prestige that in turn allows them to exert influence over the outward behaviour of the political structure. ${ }^{48}$ In turn, Weber notes, that this focus on prestige also contributes to the origin of war, in which the concept of 'honour' or 'status order' within the confines of a social structure has direct relevance to the manner in which political structures interact. ${ }^{49}$ Weber observes that this "power-orientated prestige for one's own political structure" is present from feudal lords right up to modern-day bureaucrats, in which the attainment of power for their particular political community, in turn, translates into power for themselves along with prestige attached to this power. ${ }^{50}$

However, Weber notes that there is a difference in outcome between the expansion of power for the modern bureaucrat and officer and the expansion of the power for the feudal lord. For the modern bureaucrat, the expansion of power translates into the expansion of positions

\footnotetext{
${ }^{44} \mathrm{Ibid}$.

${ }^{45}$ Weber, Max. 1991. "Structures of Power." In From Max Weber: Essays in Sociology, by H.H., Mills, C. Right. Gerth, 159-179. London: Routledge.

${ }^{46}$ Weber, Max. 1991. "Structures of Power." In From Max Weber: Essays in Sociology, by H.H., Mills, C. Right. Gerth, 159-179. London: Routledge, p. 159.

${ }^{47}$ Ibid, pp. 159-179.

${ }^{48} \mathrm{lbid}$, pp. 159-179.

${ }^{49} \mathrm{lbid}$, pp. 159-179.

${ }^{50} \mathrm{Ibid}$, p. 160.
} 
available for officers and wider opportunities for promotions. ${ }^{51}$ Whereas, for the feudal lord the expansion of power translates into the attainment of more things to assimilate and more supplies for the lord's progeny. ${ }^{52}$ Apart from these economic components to power, the "striving for prestige pertains to all specific power structures and hence to all power structures", however, Weber notes, that this striving is not synonymous with national pride nor pride in the political community to which one belongs. ${ }^{53}$ Rather, this striving for prestige, or the "prestige of power", constitutes for Weber the "glory of power over other political communities" in terms of the "expansion of power" via the use of incorporation or subjection, and in which this prestige is to be found within the largest political communities. ${ }^{54}$

On this point, Weber observes that political structures generally tend towards favouring political neighbours that are objectively weaker than themselves, however, in the case of large political structures, these have a tendency to find themselves, due to their aspirations of political prestige, in a position of endangerment on the basis that they themselves are conceived of as a threat by their weaker political neighbours. ${ }^{55}$ Weber goes on to state that, due to this dynamic that arises between political communities where claims surrounding prestige are present, these political communities tend to seek to challenge those other political communities that are perceived to have prestige. ${ }^{56} \mathrm{An}$ example of this can be seen if one looks at Great Powers, something that will be used as exemplifying a case in point.

This "sentiment of prestige" within a political community, in turn, has the capacity to "strengthen the ardent belief in the actual existence of one's own might" or in other words reify the belief in the strength of the political community to which one belongs, because of this the sentiment of prestige tends to be nurtured by those with implicit interests in political structures. ${ }^{57}$ Weber goes on to note that in the modern context those political communities that possess power prestige tend to be classified as Great Powers, in that these political communities seek to leverage political and economic influence over a wide territory. ${ }^{58}$ This leverage on the part of Great Powers, tends to take place on account of such political communities often being expansive in nature, in that they seek to expand "the territories of

\footnotetext{
${ }^{51}$ Ibid, pp. 159-179.

$52 \mathrm{lbid}$, pp. 159-179.

${ }^{53} \mathrm{Ibid}$, p. 160.

${ }^{54}$ Ibid, p. 160.

55 Ibid, pp. 159-179.

${ }^{56} \mathrm{lbid}$, pp. 159-179.

${ }^{57} \mathrm{Ibid}$, p. 161.

${ }^{58} \mathrm{lbid}$, pp. 159-179.
} 
their respective political communities by the use or the threat of force or by both", however, this is not always the case in all instances due to possible prevailing circumstances at any one time. ${ }^{59}$

This creation and expansion of "Great Power structures" can result from economic forces, and as Weber notes, economic forces as an explanation can be generalised to an extent in individual cases, in which pre-existing trade within a region serves as the foundation for the political unification of a community within a given territory. ${ }^{60}$ However, on closer inspection, one finds that this is not always the case, in that prevailing economic factors as they relate to the unification of a community can be in part accidental in so far as the economics can be either outward or inward-looking. ${ }^{61}$ In other words, external trade does not necessarily lead to the unification that underlies the great power status of a political community and that such unification can be achieved in instances where either an isolationist economics is present, or economics is treated as subservient to wider political issues. ${ }^{62}$

Weber notes that the economic structure of a political community is nevertheless a factor in the question of political expansion, especially as it relates to the scarcity of and acquisition of land as it is on the basis of land that a large portion of commercial profits can be raised, and that land is often acquired via the means of "violent political suppression". ${ }^{63}$ On this point of land as an economic factor, the manner in which land takes on the role of an economic factor changes from period to period. Weber begins his discussion on this point with a discussion of feudal and broadly feudal political communities, something that will be of later importance. Within feudal political structures in which a subsistence economy dominates the peasantry that exists upon acquired land that constitutes the expanded territory of the political community are merged into the dominant political community. ${ }^{64}$ However, once capitalism replaces feudalism, the interest in land on the part of capitalists possesses the potential to come into conflict with the interests of the peasants occupying said land. ${ }^{65}$ Here Weber utilizes the example of Rome, whose territorial expansion brought about the conditions for what was to become industrial capitalism, in which the monopolisation of profit brought

\footnotetext{
59 Ibid, p. 161.

${ }^{60} \mathrm{Ibid}, \mathrm{p} .162$.

${ }^{61} \mathrm{lbid}$, pp. 159-179.

$62 \mathrm{lbid}$, pp. 159-179.

${ }^{63} \mathrm{Ibid}$, p. 165.

${ }^{64} \mathrm{lbid}$, pp. 159-179.

${ }^{65} \mathrm{Ibid}$, pp. 159-179.
} 
about via the "direct force and compulsory labour" were utilised in order to secure the unity of the political community as it concerns its member as it concerns external opposition. ${ }^{66}$

Additionally, Weber notes that "emotional influence" plays a significant role in the maintenance of a political community, in which the "sentiments of prestige" that permeates the various positions of power within political structures and the attachments that arise from them is combined with the idea that the prevailing power structures possess a responsibility towards later generations. ${ }^{67}$ This responsibility also manifests in the manner in which great power structures "distribute power and prestige between their own and foreign polities", in which those within a political community that already possess the power necessary to "steer common conduct" will usually be the ones who see themselves as having this responsibility and perceive themselves as being the "most reliable bearers of the idea of the state as an imperialist power structure demanding unqualified devotion". 68

Moreover, outside of the direct and material interests already mentioned, ideological interests stemming from the "intellectually privileged within a polity" are also a factor, in which the influence of the intellectually privileged transforms the standard conception of the prestige of power in the idea of the nation. ${ }^{69}$ Weber subsequently holds that the concept of the nation cannot be determined within the confined of "empirical qualities common to those who count as a member of the nation", rather the concept of the nation stems from "the sphere of values" in which the concept of the nation relates to the solidarity that arises from specific sentiments that emerge in the face of other groups. ${ }^{70}$

However, Weber notes that the criteria used to separate groups in the form of nations is not agreed upon, the concept of the nation is not immediately identifiable to the members of a state and that there are numerous nations that are deemed to be independent of whatever state they so happened to find themselves within. ${ }^{71}$ Weber also observes that a nation is not necessarily identical to a community with a common language, a common religion, or a common ancestry. While these things can be used to define a nation, they nevertheless vary

\footnotetext{
${ }^{66} \mathrm{Ibid}, \mathrm{p} .168$.

${ }^{67}$ Ibid, p. 171.

${ }^{68}$ Ibid, p. 172.

$69 \mathrm{lbid}$, p. 172.

70 lbid, p. 172.

${ }^{71}$ Ibid, pp. 159-179.
} 
in aptitude for definitional purposes from place to place. ${ }^{72}$ Thus, the question of what to conclude from various national sentiments, based upon various differences, found among those within a political community is of a simultaneously variable and significant nature, in which even adherence to the concept of the nation by these groups within a political community is variable. ${ }^{73}$

For Weber, the "common object" that sits behind the concept of the nation exists within the realm of politics, in which a nation is defined as "a community of sentiment which would adequately manifest itself in the state of its own; hence, a nation is a community which normally tends to produce a state of its own". ${ }^{74}$ Subsequently, the answer to the question concerning the constitution of a nation rests on the relationship between the advocates of the nation and interests surrounding prestige. ${ }^{75}$ The "earliest and most energetic manifestations of the idea" of the nation contained the idea of a "providential mission" which was deemed to be carried by those who advocate for the nation in which this mission was to be achieved via the "cultivation of the peculiarity of the group set off as a nation". Here the justification for the nation is "sought in the value of its contents" where the providential mission can be articulated as "a specific cultural mission". ${ }^{76}$ In turn, the concept of the nation is often tied to some conception of either the pre-eminence or irreplaceability of the particular cultural values of a particular group which is to be developed and conserved via "the cultivation of the peculiarity of the group". ${ }^{77}$ Weber goes on to note the role of the intellectual in spreading the idea of the nation, in a manner similar to those "who wield power in the polity to provoke the idea of the state". For Weber intellectuals are those within a community who "by virtue of their peculiarity have special access to certain achievements considered to be cultural values and therefore usurp the leadership of a cultural community". ${ }^{78}$

Focusing only on the political component in the emergence of national sentiment the role of the state becomes preeminent, in that an existing state organisation whose perceived triumphs are not directly discerned by the masses, especially by those parts of the masses

\footnotetext{
72 Ibid, pp. 159-179.

73 Ibid, pp. 159-179.

${ }^{74}$ Ibid, p. 173.

75 lbid, pp. 159-179.

76 Ibid, p. 176.

77 lbid, p. 176.

78 Ibid, p. 176.
} 
that have culturally developed separately from the of the state, "can nevertheless be decisive for a powerful sentiment of solidarity, in spite of great internal antagonism". ${ }^{79}$ The state is capable of taking this national sentiment and using it to create a nation due to a state being valued for being able to provide security, especially in the cases where an external threat is present. ${ }^{80}$ Thus, political power, as it relates to and is expressed via both the nation and thus national sentiment, is to be found in the expression of the concept of power prestige as it is expressed within both the political community via the promotion of that communities cultural peculiarities and the functioning of the state apparatuses that take part in the governance of the political community.

Whilst discussion of Great Power politics and Nationalism are not immediately relevant for the purpose of the argument in this thesis, since neither of these two concepts impinges upon the argument or need to be utilised in the argument in any ostensible way, they are nevertheless included here for framing purposes so that the relevant elements of Weber's thought can be situated within a more complete theoretical. Their inclusion is also pertinent to illustrate the way in which Weber's thought also took note of the more negative aspects of rationalization and bureaucracy whilst also maintaining that the competition for national prestige constitutes enough in the way of political education to overcome these negative aspects.

\footnotetext{
79 Ibid, p. 177.

${ }^{80} \mathrm{Ibid}$, pp. 159-179.
} 


\section{Chapter 2: Outlining Deleuze's Society of Control}

This section shall provide the necessary theoretical background for understanding Deleuze's concept of the society of control. This section shall begin by outlining and explaining Foucault's idea of the disciplinary society as this is the concept that Deleuze is both reacting against and building upon. In so doing, the concepts of social discipline, punishment, and subject building shall be explained. The second section shall then go on to outline and explain Deleuze's concept of the society of control. In so doing, this section shall outline and explain how Deleuze conceived of the changes in disciplinary structures within society, how these differ from Foucault's articulation of social control, and how this change in control can be viewed in currently existing social formations and structures. The final section shall then outline and explain in brief both the concepts of the surveillance assemblage that serves as the primary mechanism through which the society of control operates.

\section{Foucauldian Background}

In 1975, Foucault published his work Discipline and Punish. In this work, he presented a genealogical study concerning the development of the modern approach to criminality in which imprisonment became to be favoured over torture or mere killing. While Foucault recognised the aspects of modern incarceration that brought about improvements, he nevertheless emphasised the way in which these improvements became tools that ushered in more effective means of control. He went on to argue that these new forms of punishment became the model via which societal control in its entirety would come to be controlled, with institutions and workplaces becoming modelled after the prison. This was not due to conscious decisions, but rather was the result of a convergence that Foucault noted that takes place between institutions that were created for various purposes that together create "the modern system of disciplinary power" ${ }^{81}$

Foucault identified three main forms of control within the confines of the modern disciplinary society: namely those of "hierarchical observation, normalising judgment, and the examination". 82 Here Foucault noted that for the most part, "control over people can be

\footnotetext{
${ }^{81}$ Gutting, Gary and Oksala, Johanna. 2018. "Michel Foucault." The Stanford Encyclopedia of Philosophy. May 22. Accessed July 13, 2020. https://plato.stanford.edu/entries/foucault/; Foucault, Michel. 1975. Surveiller et punir. Paris: Gallimard. 82 Ibid.
} 
achieved merely by observing them" ${ }^{83}$ In a model system of observation, one person would be able to view everything that people engaged in, but since this is not normally a phenomenon that arises in real societies and institutions (outside of exceptions like Bentham's Panopticon) it is necessary to have a number of observers that exist in a hierarchy and keep note of the data that passes through each stage of the hierarchy. ${ }^{84}$

For Foucault, a notable component of "modern power (disciplinary control) is its concern with what people have not done (nonobservance)", namely the standard that people have not reached. ${ }^{85}$ Nonobservance, i.e. not achieving a particular standard or adhering to a certain norm, serves as the main illustration for modern disciplinary society, namely correcting that which is taken to be deviant behaviour. ${ }^{86}$ The goal of a disciplinary society is that of reform, as opposed to punishment, which amounts to getting subjects to uphold the norms and standards of the society, in which discipline is instilled via the adherence to these norms resulting in pervasive "normalization" of those norms. ${ }^{87}$ In line with this, the examination (such as those in the form of a test or of a medical patient) "is a method of control that combines hierarchical observation with normalizing judgment" and is a model example of Foucault's notion of power/truth which utilizes "the deployment of force and the establishment of truth", in which truth is produced about the person who partakes in the examination and control of their behaviour is achieved. ${ }^{88}$ For Foucault, "at least for the study of human beings, the goals of power and the goals of knowledge cannot be separated: in knowing we control and in controlling we know" ${ }^{89}$

Additionally, examinations also place a person within a "field of documentation" in which outcomes of examinations are recorded in order to provide detailed information about the person who has undergone the examination and thus in turn allows for systems of power to exert control over that person. ${ }^{90}$ These records stemming from examinations allow for the creation of various forms of "categories, averages, and norms that are in turn a basis for

\footnotetext{
83 Ibid.

84 Ibid.

85 Ibid.

86 Ibid.

87 Ibid.

88 Ibid.

89 Ibid.

90 Ibid.
} 
knowledge" and thus transform an individual person into a "case" that serves as an example and needs to be cared for in some way. ${ }^{91}$

In Foucault's thinking, Jeremy Bentham's Panopticon serves as a model architectural representation of disciplinary power because, as a prison design, it "is built so that each inmate is separated from and invisible to all others in separate cells and each inmate is always visible to the monitor situated in the central tower" ${ }^{92}$ These monitors are not always viewing each inmate, however, these monitors could at any time view them, and because of this, the inmates are always unaware of when they are and are not being observed and thus engage in self-policing behaviour. ${ }^{93}$ Thereby, "control is achieved more by the possibility of internal monitoring of those controlled than by the actual supervision or heavy physical constraint". ${ }^{94}$ The underlying concept of the Panopticon "can be applied not only to prisons but also to any system of disciplinary power" and has thus become the concept that permeates modern society as the tool through which modern discipline is exercised. ${ }^{95}$

In presenting this line of genealogical thought, Foucault follows both Nietzsche along with Phenomenology in terms of making the body the focus of history and thus presenting genealogies that are "histories of the body" as opposed to merely histories of ideas which "examine the historical practices through which the body becomes an object of techniques and deployments of power" ${ }^{96}$ Foucault's approach in Discipline and Punish illustrates how the techniques of discipline create "docile bodies" or bodies that after being exposed to disciplinary power become easier to control. For these forms of disciplinary power, the human body is conceptualised of as a machine that can be improved upon in accordance with some standard. ${ }^{97}$ Foucault's historical genealogies thereby bring into question the "naturalistic explanatory framework that underlies human nature - uncovered by science - as the basis for such complex areas of behaviour as sexuality, insanity or criminality". ${ }^{98}$ A primary component of Foucault's historical genealogy is that it uncovered the dual role of the modern

\footnotetext{
${ }^{91}$ lbid.

92 Ibid.

$93 \mathrm{lbid}$

${ }^{94}$ Ibid.

$95 \mathrm{lbid}$.

${ }^{96} \mathrm{Ibid}$.

97 Ibid.

${ }^{98} \mathrm{lbid}$.
} 
disciplinary system, namely that "it aims at both punishing and correcting, and therefore it mixes juridical and scientific practices". 99

\section{Deleuze's Concept of the Society of Control}

In very basic terms, a Society of Control is a society that uses control instead of discipline in the policing of Subjects in which free acts of volition on the part of the Subject are used as a means of control by social institutions. ${ }^{100}$ As was already outlined previously, Foucault articulated a disciplinary society as a society that introduces "the organization of vast spaces of enclosure" in which the individual "never ceases passing from one closed environment to another, each having its own laws". ${ }^{101}$ These organizations include "first the family; then the school; then the barracks; then the factory; from time to time the hospital; possibly the prison" and in which the prison "serves as the analogical model". ${ }^{102}$ While Foucault "analysed the ideal project of these environments" he was also aware that this was a temporary state of affairs. Society would not always be constructed in this way. Just as the disciplinary society replaced societies of sovereignty so too would the disciplinary society be replaced. ${ }^{103}$ Based upon this observation, Deleuze argued that just as the disciplinary society arose out of crises in the societies of sovereignty, societies of control arose out of crises in disciplinary societies: "we are in a generalized crisis in relation to all the environments of enclosure - prison, hospital, factory, school, family". ${ }^{104}$ For Deleuze, this crisis is a crisis of interiority in which the confinements of a disciplinary society are no longer able to achieve their intended task of disciplining social beings in a certain way. ${ }^{105}$ Subsequently, Deleuze uses the word "Control", borrowed from Burroughs and recognized by Foucault, as the term to describe the society that would emerge after disciplinary society. ${ }^{106}$ This society would be constituted, following the observations of Paul Virilio, by an "ultra-rapid form of free-floating control that replaced the old disciplines operating in the time frame of a closed system". 107

\footnotetext{
99 Ibid.

${ }^{100}$ Deleuze, Gilles. 1992. "Postscripts on the Society of Control." October 59: 3-7.

101 Ibid, p. 3.

102 Ibid, p. 3.

$103 \mathrm{lbid}$

104 Ibid, p.3.

${ }^{105} \mathrm{lbid}$, pp. 3-7.

106 Ibid, pp. 3-7.

107 Ibid, p.4.
} 
Deleuze goes on to outline the logic that is used by such a society and how this logic deviates from that of disciplinary society. In a disciplinary society a Subject is "always starting again (from school to the barracks, from the barracks to the factory), while in the societies of control one is never finished with anything - the corporation, the education system, the armed services being metastable states coexisting in one and the same modulation, like a universal system of deformation". ${ }^{108}$ Deleuze held that disciplinary society, in turn, unites two components, one individual and one collective, namely the representation of the individual on the one hand and the representation of the individuals place within a collective mass on the other and in so doing forms both the individual and the collective in relation to each other. ${ }^{109}$ Juxtaposed to this, Deleuze held that societies of control have neither the representation, nor "signature", of the individual or the representation of the individual's place, or "number", but rather "codes that mark access to information, or reject it". ${ }^{110}$ In other words, societies of control exert power through the collection and management of flows of information that has been collected from the subjects within that society. Deleuze goes on to state that individuals "have become 'dividuals' and masses, samples, data, markets, or "banks'". ${ }^{111}$ To explicate this distinction between the two forms of society further, Deleuze uses the example of money in which "discipline is always referred back to minted money that locks gold in as numerical standard, while control relates to floating rates of exchange, modulated according to a rate established by a set of standard currencies". ${ }^{112}$

In articulating this, Deleuze is only articulating that a change in the functioning of power and its relations is taking place, he does not hold that we have fully discovered all the ways in which social control impinge upon the individual and the full implications of how such a shift in the functioning of power will affect over those this power is wielded. ${ }^{113}$ Thus, there is a degree with which any exploration of the Society of Control at this point, especially in a theoretical sense, is going to possess a degree of abstractness. Nevertheless, Deleuze does set out the basics of what we can expect to see. To restate the crux of the previous paragraph in more concrete terms, with the creation of and shift towards the various forms of technology related to information that took place after the Second World War, there was now the ability for the Capitalist paradigm to allow a population to move far more freely without

\footnotetext{
108 Ibid, p.5.

${ }^{109} \mathrm{lbid}, \mathrm{pp} .3-7$.

110 Ibid, p.5.

111 lbid, pp. 3-7.

112 Ibid, pp. 3-7.

113 Ibid, pp. 3-7.
} 
the need to compromise control. New technologies such as electronic banking, remote surveillance, network monitoring, biometrics, genetic engineering, and so forth all allow the Capitalist paradigm to maintain and extend the hold that it possesses over the Subject while at the same time mitigating traditional forms of opposition on the part of the population. ${ }^{114}$ In outlining this, Deleuze is articulating the way in which the Society of Control is able to expand the horizons, both physical and nonphysical beyond that of confinement, while at the same time increasing the potency of this control and in doing so making the parameters of enclosure largely imperceptible to the Subject. ${ }^{115}$

In this way, Societies of Control "generate their own technologies and processes of subjectivation, which as noticeably different from the technologies and processes of subjectivation of disciplinary societies" where "power relations come to be expressed through the action at a distance of one mind on another, through the brain's power to affect and become affected, which is mediated and enriched by technology: The mechanical means designed to carry far and loud the suggestive action of the leader (words, writing, print) do not cease their progress". ${ }^{116}$ Thereby, "the institutions of societies of control are thus characterized by the use of the technologies of acting at a distance, rather than of mechanical technologies (societies of sovereignty) or thermodynamic technologies (disciplinary societies)" ${ }^{117}$

When Deleuze speaks of a Society of Control using a subject's actions as a means of control, especially in the socio-political context, he is, in essence, talking about large scale initiatives concerning various forms of data collection and use on the part of a government, State, private corporation, or any institutionally notable actor. These initiatives in essence constitute the monitoring of subjects going about their ordinary lives and using their everyday decisions and actions as sites from which data and information are to be gathered. In other words, these initiatives are predicated on a subject's utilizing their freedom in order to generate the data and information that is to be gathered. And in a potential mature articulation this would be articulated by what Kevin Haggerty and Richard Ericson call a "surveillant assemblage" that

\footnotetext{
${ }^{114}$ Ibid, pp. 3-7.

$115 \mathrm{Ibid}$, pp. 3-7.

${ }^{116}$ Lazzarato, Maurizio. 2006. "The Concepts of Life and the Living in the Societies of Control." In Deleuze and the Social, by Martin Fuglsang and Bent Meier. Sørensen, 171-190. Edinburgh: Edinburgh University Press, p. 180. ${ }^{117}$ Ibid.
} 
constitutes a "post-panoptic surveillance. ${ }^{118}$ Such a "post-panoptic surveillance" is constituted by the following:

1). “...the desire to bring systems together, leading to an increased convergence of formerly discrete surveillance systems and an exponential increase in surveillance capacity;"119

2). “...is increasingly growing and spreading by expanding its uses for purposes of control, governance, security, profit, and entertainment, and with the help of new and intensified technological capabilities, particularly the rise of computerised databases;"120

3). “...has a levelling effect on hierarchies of surveillance, due to new target populations being monitored with new and intensified technological possibilities;"121

4). “...works across state as well as non-state institutions;"122

5). “...is primarily directed towards human bodies that are understood as a hybrid composition-a flesh-technology-information amalgam;"123

6). "...relies on machines to make and record discrete observations." 124

While all of these different actors are vital components for our understanding, our focus shall nevertheless be on the government and State as this is the level at which a leadership democracy is present. Thus, when we speak of a society of control utilizing freedom as a means of control, what we are in essence talking about are the structural ways in which a government, the State, and institutional actors of one sort or another leverage large scale data collection to manipulate the outcomes of the population in their favour over time. At first glance, with this specific focus upon the political sphere, one might assume that this largely begins and ends with phenomena such as various forms of political nudging such as

\footnotetext{
${ }^{118}$ Galič, Maša, Tjerk Timan, and Bert-Jaap. Koops. 2017. "Bentham, Deleuze and Beyond: An Overview of Surveillance Theories from the Panopticon." Philosophy \& Technology 30: 9-37. 119 Ibid, p. 21.

120 lbid, p. 21.

${ }^{121} \mathrm{Ibid}$, p. 21.

$122 \mathrm{lbid}$, p. 21.

${ }^{123} \mathrm{Ibid}$, p. 21.

${ }^{124}$ Ibid, p. 22.
} 
political advertising via media channels the likes of which one finds in standard democratic countries. While such a phenomenon would certainly be present, this is not fundamentally what is being referred to here.

Rather, what is being referred to here is something far more encompassing which is better articulated by phenomena such as the wide-spread surveillance and social credit system that the likes of the Chinese government have proposed or the widespread spying on citizens conducted by the National Security Agency in the United States and in general post 9/11. Another example that could be called upon is the broad idea of the smart city that is found in concrete examples of "urban projects, master plans, policy papers, corporate strategies, and municipal imaginaries" that are "grounded in an eschatological optimism concerning the convergence between urban and IT developments based on intensive rather than extensive growth". 125 These projects entail that "the ubiquitous presence of digital, interactive technologies in urban environments, households and as citizens' personal devices will optimise patterns of consumption and communication, and assert the centrality of interactive Big Data - as real-time streams and cumulative patterns - in perfecting urban dynamics and governance". ${ }^{126}$ However, while these concrete cases of China and the USA are a useful starting point to conceptualize a Society of Control, it is ostensibly the case that both example cases possess a form of coercion that is still too overtly disciplinary in the Foucauldian sense to constitute a full Society of Control when one looks at the overall functioning of institutions in each case. One can ask the question of whether there is any country today that is purely a Society of Control and the answer would ostensibly seem to be a negative. Despite this, it is nevertheless the case that one can theorize about the possibilities surrounding a Society of Control and how such a thing interacts with other theoretical positions concerning the nature and functioning of institutions within a society, something that this thesis is concerned with. Subsequently, for the rest of this work, when a reference is made to the mechanisms of a Society of Control it is what has been laid out here in this specific section that is being referred to.

The idea of assemblages was formulated by Deleuze and Guattari as consisting "of a multiplicity of heterogeneous objects, whose unity comes solely from the fact that these items function together, that they work together as a functional entity" and "comprise

\footnotetext{
${ }^{125}$ Krivý, Maroš. 2018. "Towards a critique of cybernetic urbanism: The smart city and the society of control." Planning Theory 17 (1): 9.

${ }^{126}$ Ibid
} 
discrete follows of an essentially limitless range of other phenomena such as people, signs, chemicals, knowledge, and institutions". ${ }^{127}$ Such assemblages were for Deleuze and Guattari an aspect of the "state form". ${ }^{128}$ This state form seeks to impose physical and cognitive boundaries that are used to "capture flows", in that the "state seeks to striate the space over which it reigns" in which breaks a separation is imposed on free-flowing phenomena. ${ }^{129}$

In turn, this action on the part of the state becomes a means through which the state and its various institutions can "direct or govern the actions of others". ${ }^{130}$ This, in turn, leads to the concept of rhizomatic surveillance which underlies the notion of a surveillance assemblage which is, in turn, the mechanism of the society of control. "Rhizomes grow across a series of interconnected roots which throw up shoots in different locations" which "grow like weeds" and which may be "broken, shattered at a given spot, but it will start up again on one of its old lines, or on new lines". ${ }^{131}$ Likewise, surveillance possesses a similar "expansive and regenerative quality" in which Deleuze and Guattari highlight how " the rhizome operates by variation, expansion, conquest, capture, offshoots" in which there is not one technological development that has brought about the modern era of surveillance. ${ }^{132}$ However, the expansion of modern surveillance has "been aided by subtle variations and intensifications in technological capabilities, and connections with other monitoring and computing devices" ${ }^{133}$ This is important to note because it means that a society of control cannot be reduced to one form of surveillance that a particular regime may engage in. It cannot be reduced solely to phenomena such as trying to influence voters during an election campaign or to phenomena such as harvesting data from social media even though both of these are certainly part of

\footnotetext{
${ }^{127}$ Haggerty, Kevin D, and Richard V. Ericson. 2000. "The surveillant assemblage." British Journal of Sociology 51 (4): 608; Patton, P. 1994. "MetamorphoLogic: Bodies and Power in A Thousand Plateaus." Journal of the British Society of Phenomenology 25 (2): 158.

${ }^{128}$ Haggerty, Kevin D, and Richard V. Ericson. 2000. "The surveillant assemblage." British Journal of Sociology 51 (4): 608.

${ }^{129}$ Haggerty, Kevin D, and Richard V. Ericson. 2000. "The surveillant assemblage." British Journal of Sociology 51 (4): 608; Deleuze, Gilles, and Felix. Guattari. 1987. A Thousand Plateaus. Minniapolis: University of Minnesota Press: 385.

${ }^{130}$ Haggerty, Kevin D, and Richard V. Ericson. 2000. "The surveillant assemblage." British Journal of Sociology 51 (4): 609; Patton, P. 1994. "MetamorphoLogic: Bodies and Power in A Thousand Plateaus." Journal of the British Society of Phenomenology 25 (2): 161.

${ }^{131}$ Haggerty, Kevin D, and Richard V. Ericson. 2000. "The surveillant assemblage." British Journal of Sociology 51 (4): 614; Deleuze, Gilles, and Felix. Guattari. 1987. A Thousand Plateaus. Minniapolis: University of Minnesota Press: 9.

${ }^{132}$ Haggerty, Kevin D, and Richard V. Ericson. 2000. "The surveillant assemblage." British Journal of Sociology 51 (4): 614. Deleuze, Gilles, and Felix. Guattari. 1987. A Thousand Plateaus. Minniapolis: University of Minnesota Press: 21.

${ }^{133}$ Haggerty, Kevin D, and Richard V. Ericson. 2000. "The surveillant assemblage." British Journal of Sociology 51 (4): 615.
} 
societies of control. Rather one has to look at the entirety of control and surveillance, one has to look at it as an assemblage if one is to make sense of a society of control.

Going forward, this is also pertinent when thinking about examples. Because Deleuze, unlike Foucault, was engaging in speculative theorizing and so a degree of this speculative nature is going to carry over for the following reason. Namely, that at this time of writing it is ostensibly the case there are no regimes currently in existence that are pure societies of control, rather there are regimes that exhibit different aspects that go towards constituting a society of control in forms of various kinds of surveillance assemblages. Thereby, the question, that of the effect of a society of control on a leadership democracy, is a question of theory in the pure and abstract sense of the term, where reference back to real-world regimes will be of limited use. 


\section{Chapter 3: Leadership Democracy within a Society of Control}

This section will present the main argument concerning how a charismatic leader at the helm of a leadership democracy can overcome the effect of a society of control. It will be argued here that despite the presence and imposition of a society of control that a charismatic leader at the helm of a leadership democracy can break through and overcome the mechanisms of a society of control. In so doing, this section will be split into three sections. The first will cover the relationship between a charismatic leader, leadership democracy, and the society of control. In so doing, it shall present a case for how a society of control could be argued to lead to an imposition upon both the charismatic leader and leadership democracy such that both are constrained. The second will cover the way in which the conclusion of the former section can be circumvented. In so doing, it shall present a case for why one should not see the presence of the society of control as being an imposition upon a charismatic leader's autonomy such that the charismatic leader loses the degree of freedom needed for them to overcome and break through the society of control. Finally, the third will cover the way in which this continued presence of a charismatic leader's freedom can translate over into the wider socio-political institutions. In so doing, it shall present a case for how a leadership democracy is not affected by a society of control.

\section{The Charismatic Leader, Leadership Democracy, and a Society of Control}

Recapping what was articulated previously, under the political realism that Weber advocated, self-rule by the people in the truest sense of the concept is either highly problematic at best if not an outright impossibility at worst. ${ }^{134}$ This forces a choice between a democracy that either possesses leadership or is leaderless. ${ }^{135}$ In the case of a leadership democracy, Weber had in mind a democracy that possess a political marketplace where strong charismatic leaders could be recognized and elected by winning votes in free competition, with an emphasis on the role of conflict as the primary mechanism via which leadership of the nation with the necessary strength to control the governing bureaucracy can be created. ${ }^{136}$ Thereby, the cultivation of certain character attributes, such as charisma, is seen as vital. ${ }^{137}$ The finer

\footnotetext{
${ }^{134}$ Kim, Sung Ho. 27. "Max Weber." The Stanford Encyclopedia of Philosophy. November 2017. https://plato.stanford.edu/entries/weber/.

135 Ibid.

136 Ibid.

137 Glassman, Ronald M. 1984. "Manufactured Charisma and Legitimacy." In Max Weber's Political Sociology: A Pessimistic Vision of a Rationalized World, by Ronald M., Murvar, Vatro. (ed.) Glassman, 217-235. Westport: Greenwood Press, pp. 217-218; Weber, Max. 1978. "Charisma and its
} 
points of this have already been articulated previously so these points will not be restated here.

For Weber, charisma was not merely a sociological concept, but rather a means via which some of the developments of the modern world could be mitigated. ${ }^{138}$ However, due to the realism inherent in Weber's conception of the world, he also noted two trends in the modern world that were anti-charismatic. First, charisma has been depersonalized; and second charisma has been disenchanted that due to the rationalization of the world. ${ }^{139}$ This creation of depersonalized charisma or manufactured charisma along with the constraining of pure charisma within a rationalized society is a necessary component within the contemporary political systems that is legitimized, and which is carried forth via the effects of mass media upon the general population. ${ }^{140}$

But first let one distinguish between two different forms of administrative leadership, that of task leadership and charismatic leadership. ${ }^{141}$ The first of these, task leadership, rests solely upon the ability of an individual to carry out a particular task that is needed for group success, given this, there may be multiple leaders in a group relating to how many tasks there may be and the skill sets of the individuals within the group. ${ }^{142}$ Arguably, the bureaucracy itself

Transformation." In Economy and Society 2, by C. Wittich. G. Roth., 1111-1157. Berkeley: University of California Press, pp. 1111-1113.

138 Glassman, Ronald M. 1984. "Manufactured Charisma and Legitimacy." In Max Weber's Political Sociology: A Pessimistic Vision of a Rationalized World, by Ronald M., Murvar, Vatro. (ed.) Glassman, 217-235. Westport: Greenwood Press, pp. 217-218; Weber, Max. 1978. "Charisma and its Transformation." In Economy and Society 2, by C. Wittich. G. Roth., 1111-1157. Berkeley: University of California Press, pp. 1111-1113.

${ }^{139}$ Glassman, Ronald M. 1984. "Manufactured Charisma and Legitimacy." In Max Weber's Political Sociology: A Pessimistic Vision of a Rationalized World, by Ronald M., Murvar, Vatro. (ed.) Glassman, 217-235. Westport: Greenwood Press, pp. 217-218; Weber, Max. 1978. "Charisma and its Transformation." In Economy and Society 2, by C. Wittich. G. Roth., 1111-1157. Berkeley: University of California Press, pp. 1111-1113.

${ }^{140}$ Glassman, Ronald M. 1984. "Manufactured Charisma and Legitimacy." In Max Weber's Political Sociology: A Pessimistic Vision of a Rationalized World, by Ronald M., Murvar, Vatro. (ed.) Glassman, 217-235. Westport: Greenwood Press, pp. 217-219.; Weber, Max. 1978. "Charisma and its Transformation." In Economy and Society 2, by C. Wittich. G. Roth., 1111-1157. Berkeley: University of California Press, pp. 1111-1114.

${ }^{141}$ Glassman, Ronald M. 1984. "Manufactured Charisma and Legitimacy." In Max Weber's Political Sociology: A Pessimistic Vision of a Rationalized World, by Ronald M., Murvar, Vatro. (ed.) Glassman, 217-235. Westport: Greenwood Press, pp. 217-219; Weber, Max. 1978. "Bureacracy." In Economy and Society 2, by C. Roth, G. Wittich, 956-1005. Berkeley: Berkeley University Press, pp. 956-1002. 142 Glassman, Ronald M. 1984. "Manufactured Charisma and Legitimacy." In Max Weber's Political Sociology: A Pessimistic Vision of a Rationalized World, by Ronald M., Murvar, Vatro. (ed.) Glassman, 217-235. Westport: Greenwood Press, p. 218. 
exemplifies the complete institutionalization of task leadership, where it is an effective means of organization in the pursuit of the completion of a set of specific tasks within a complex modern society. ${ }^{143}$

However, this mere accomplishment of various tasks is usually not one of the primary issues within the political process. People are for the most part unmoved by this function of bureaucracy and merely see it as a necessary component of the completion of complex tasks within expansive societies, and it is from the acceptance of this function of bureaucracy that bureaucracy gains its legitimacy. ${ }^{144}$ Due to this bureaucracy has always been attached to some other system of legitimation. ${ }^{145}$ Two additional processes that distinguish leadership within politics are those of power and leadership built around morale enhancement. ${ }^{146}$

Power here concerns the maintenance and protection of a given territory along with the ability to maintain domestic order and distribution primary needs. ${ }^{147}$ For Weber, this in the form of power leadership was a form of illegitimate domination in which various forms of instability would plague such a political system due to the excessive use of force and coercion over the populace who in turn would see this as illegitimate on the part of the leadership. ${ }^{148}$ On the other hand, leadership based on morale enhancement of both group and individual is based on neither some specific task nor outright force, rather it is based upon an ability possessed by certain individuals to inspire others to action, namely that of charisma. ${ }^{149}$

Now, the first view that emerges from Weber's work is that charisma is not something that can be cultivated as such in a person who does not already possess the trait. Charisma can be nurtured and refined in those who innately possess it, but it cannot be taught to someone who does not possess the trait. Thereby to talk of the cultivation of manufacturing of charisma at first seems to be contradictory. However, in practice, it may be observed the close association of a person to a charismatic leader in many cases bestows charisma onto others

\footnotetext{
${ }^{143}$ Ibid.

144 Ibid.

145 Ibid.

${ }^{146}$ Ibid, p. 219.

147 Ibid, p. 218.

148 Ibid, pp. 218-219.

149 lbid.
} 
up to and including the point where even if the charismatic leader dies a close associate will often be turned to by the group. ${ }^{150}$

The primary means through which the creation of charisma takes place is through the successful formation of physical and psychological greatness in which any individual could come to appear as being charismatic, however, the access to the necessary environment in which this can take place is nevertheless limited within the confines of modern society and is thereby extended only to a select few. ${ }^{151}$ In cases such as this alienation and a breakdown of unity within a group can take place due to those outside of the select section of society becoming delegitimized. ${ }^{152}$ In order to counter this alienation and breakdown, the recognized leadership introduces factors such as cooperation, ideology, and at times force as means through which to counter these things. ${ }^{153}$

However, the manufacturing of charisma needs to be understood in relation to the process of legitimacy which can be articulated as consent to be led, where such giving consent to be led is largely unique to humans. ${ }^{154}$ For Weber, this stemmed from the human consciousness which led to both rationality and irrationality and subsequently leads to both a rational and irrational legitimacy. ${ }^{155}$ The rational aspect can be separated into the set of categories: participating in activity relating to the making of decisions, rules, the interpretation of those rules, and the choosing of leaders and access to leadership offices; the limiting of leaders concerning their power and tenure; and law concerning debates, changeable rules for the maintaining of collective order, overarching guidelines for leaders as it relates to constitutional law, and citizens' protection. ${ }^{156}$ The irrational aspect can be separated into the set of categories: pure charisma; manufactured charisma; ideological manipulation; cooptation; and coercion. ${ }^{157}$ Now, while it is the case that no leadership over a polity can rule solely through the use of coercion it is nevertheless the case that various forms of coercion can be used alongside the process of legitimacy especially where full consent of the governed

\footnotetext{
${ }^{150}$ Ibid.

${ }^{151}$ Ibid, pp. 220-221.

152 Ibid.

153 Ibid, p. 221.

154 Ibid.

155 Ibid.

${ }^{156}$ Ibid, p. 222.

157 Ibid.
} 
is never fully achieved or in cases where the polity is so large as to mitigate against full participation in the legitimacy process. ${ }^{158}$

The charisma of the leader in a leadership democracy represents a case of irrational legitimacy on the basis that the member within the group under which the charismatic leader presides feels as though they have some form of relationship with the leader despite having little to no personal contact with the leader. This in turn creates a situation in which the individual places trust in the leader and consents to the leader's rule. ${ }^{159}$ Because of this, the leader is capable of leveraging large degrees of power while the people over whom the leader presides will in many cases consent to the will of the leader even in cases where the longterm interests of the people are not met. ${ }^{160}$ Due to charismatic leadership being the one form of leadership in which large scale control is combined with large scale consent and because charisma can be transferred to those within the close circle of the charismatic leader the manufacturing of charisma has been treated as a matter of importance for the creation of a form of permanent leadership. ${ }^{161}$

Within modern societies, namely societies in which modern communication technologies are present and in which control over the flows of information is possible, those that seek to rule can exploit this technology in order to manufacture charisma in order to accomplish societal integration and to give their taking of power a degree of legitimacy. ${ }^{162}$ One conceivable method via which this takes place is through the use of mass media which can be utilized to present a leader as being always present and often larger than life because a charismatic relationship works best when the group feels a trusting and personal bond with a given leader. ${ }^{163}$ However, there are also obstacles to the manufacturing of charisma via the use of mass media in the form of Weber's conception of rationality. ${ }^{164}$

Modernity has brought about a rationalized, skeptical, and empirically driven type of world view where humans are seen to be objects unto themselves, which in turn causes attempts at the manufacturing of charisma to be scrutinized as an object of study and thus be revealed

\footnotetext{
158 Ibid, p. 223.

159 Ibid.

${ }^{160}$ Ibid, pp. 223-224.

161 Ibid, p. 224.

162 Ibid, pp. 224-226.

$163 \mathrm{lbid}$, p. 226.

$164 \mathrm{Ibid}$, p. 231.
} 
as just such an attempt of manufacture. ${ }^{165}$ Another difficulty that can arise is that modern societies are made up of multiple groups and multiple classes which poses problems concerning widespread legitimacy in that the potential charismatic leader will often fail to be charismatic to all portions of the population simultaneously and because of this a potential leader can lose their charisma via propaganda. ${ }^{166}$

Additionally, the proliferation of bureaucratic institutions brings about a state of affairs in which charisma is intentionally removed from leadership and replaced with a structure that splits leadership into a network of hierarchies where charismatic leadership is not necessary for cohesion and is in fact discouraged. ${ }^{167}$ The problem that emerges, however, is that bureaucratic political leadership does not in and of itself create structures of legitimacy in the wider sense, additionally, the alienation that can emerge within such bureaucratic organizations can push people towards charismatic leadership. ${ }^{168}$ Because of this possible alienation and lack of structures of legitimacy, bureaucratic structures, despite discouraging charismatic leadership, cannot truly exist apart from charismatic leadership and thus the possibility arises that within the confines of modern society bureaucracy pushes people towards straightforward welcoming of charismatic leadership while modern rationality makes charismatizing difficult. ${ }^{169}$ Additionally, there is the potential limiting of rational political procedures on the basis that bureaucracy possesses its own rationality and hierarchical structure which is at odds with a rationalised articulation of political participation, choice of leadership, and the copying of certain leaders. ${ }^{170}$

However, in the case of the society of control, these problems of not only legitimacy but also of charisma can be overcome by a charismatic leader. In the case of legitimacy, it is a requirement for any well-functioning political bureaucracy that they maintain at the very least the appearance of a mandate from those over whom they rule. A problem that seemingly emerges in the presence of a society of control is that since the charismatic leader or leaders are themselves subjects within the society of control and are at the head of institutions that can utilize the mechanisms of the society of control in various ways, how is it that they can

\footnotetext{
165 Ibid.

166 Ibid.

167 Ibid, p. 232.

168 Ibid.

169 lbid.

170 lbid.
} 
break through the imposition of the said society of control? The first thing to note is that the society of control provides a means through which information can be collected and utilized within a polity. Within a society of control, a bureaucratic political structure possesses the tools via which it can collect information about the members of the polity using a variety of tools and methods, some of which would arguably be seen as being an impediment within older societal constructions such as a disciplinary society.

Additionally, bureaucratic political institutions do not need to use large degrees of coercion in order to elicit the required information from the members of the polity, rather these bureaucratic structures merely need to allow for the free exchange of speech and ideas within a public or semi-public setting along with the monitoring of locations and physical traces of the body. Through the allowing of largely free expression of speech and ideas those within the polity inadvertently create flows of information surrounding particular socio-political topics that bureaucratic political structures can harvest for relevant data that they can then utilize in order to present themselves to the polity in such a way as to be always legitimised to as many people as possible at once through the use of the very same channels from which the created information flows originated. One could object that this assumes a degree of ease with which the relevant flows of information can be harvested and usefully categorized.

In the case of charisma, as it is related to Weber's leadership democracy, it is a requirement for any well-functioning political bureaucracy to be headed by a leader that can both inspire to action those over whom they preside and also create or at the very least given the impression of unity within a bureaucratic structure. Once again, as previously discussed, modern societies that are societies of control pose a problem in that the charismatic leader or leaders are themselves subjects within the society of control and while at the head of institutions that can utilize the mechanisms of the society of control.

Now, suppose that we have a society in which a polity is constituted by free subjects and is presided over by a regime in which a leadership democracy is present and in which the government upholds standard freedoms such as freedom of speech, freedom of expression, freedom of association, and so forth. Let us now also suppose that this government does not engage in standard forms of covert coercion, i.e., the use of some form of secret police, and let us also suppose that this society is a modern technological society. How is it then the case, that in such a society, that a leadership democracy can become only democratic in name and not in proper content despite the upholding of standard liberal freedoms? 
The means by which this can take place emerges from the interaction between the political bureaucratic structures and the wider polity within a society. In a liberal society that upholds standard liberal freedoms, the subject is free to pursue their will in the manner previously described, in which a subject is broadly free to a certain thing at a certain time with the capacity to have done otherwise as they had chosen. But at the same time as people are pursuing their will in relation to liberal freedoms, the problems of legitimacy and charisma emerge as noted previously. Such subjects within such a polity do not necessarily respond to the mechanisms of a Disciplinary Society, in that they, via the pursuit of their freedom, can no longer be shaped into the kinds of subjects in which the representation of the individual and the individuals' place within the wider polity can be united through a single charismatic leader, as noted by Deleuze.

In such a case where individual and collective representation, as noted in the previous paragraph, either faces difficulty in its realisation or cannot be achieved at all, the relationship between the subjects of the polity and the bureaucratic political structures begins to shift in such a manner that the bureaucratic political structures can begin to lose their degree of power over the subjects of the polity due to said structures beginning to fail to create subjects that either accept the nature of the bureaucratic structures and/or are willing to participate in them. Additionally, the subject's pursuit of their will writ large creates the dissemination of differences between groups and classes within the polity that goes towards posing these issues surrounding a subject's lack of response to disciplinary mechanisms and charismatic leadership as noted previously.

However, in the case of a subject pursuing their own freedom within the confines of such a society and polity, in a state where such freedoms are upheld, such a subject nevertheless creates flows of information about themselves in the process of pursuing their will in as free a manner as possible. This creation of flows of information, in turn, provides information about the subject that can be harvested by a bureaucratic political structure that can, in turn, use such information in order to present both the charismatic leader and the wider bureaucratic political structure to the subject in such a way that the subject will be willing to accept the nature of and the rule of said bureaucratic political structure or present options to the subject such that these options lead to an outcome sanctioned by said bureaucratic structures. In this way, such bureaucratic political structures as they relate to a leadership democracy are capable of maintaining legitimacy within a polity and promoting charisma. 
However, in doing so, such a leadership democracy within a society of control is nevertheless engaging in a kind of activity that would on the face of things seem to be at odds with how we conceptualise a liberal society. Proper liberal societies are generally not conceived of as having such an underlying mechanism of control in which subjects' free acts are harvested for data that political bodies can then exploit for their own benefit, at least not to this degree. Thus, due to the level of inadvertent surveillance that emerges in the process of bureaucratic political structures within a leadership democracy harvesting such data in order to ensure the manufacturing of legitimacy and charisma over time, it would seem reasonable to argue that some form of non-democracy, and authoritarianism, in particular, has emerged.

However, outside of the role of increased surveillance, the question of coercion reappears in an otherwise interesting form. Control and government coercion are still taking place even though the freedom of the subject is not being violated in any traditional sense whereby the subject would be prevented from doing otherwise at a particular moment. Now, one may raise the observation that the statement seems to imply something close or identical to Ideological Power as per Steven Lukes as opposed to being related back to the role of free will as possessed by the subject. ${ }^{171}$ Such an observation would seemingly be correct in so far as a kind of ideological power of some description would ostensibly be operational, however, the focus upon free will in relation to control is still central here due to the emphasis being on how a subject is still able to do otherwise due to the specifics of the kind of control this thesis is concerned with and while it is the case that society of control as per the Deleuzian is concerned by and large with the tracking of subjects within non-confined spaces and not particularly concerned with either ideological persuasion or manufacturing consent, it is nevertheless the case that this tracking of subjects and the mechanisms relating thereto are most certainly of use to those interested or invested in both ideological persuasion and manufacturing consent.

Rather, this control and coercion emerge as a result of knowing enough about the subject to offer said subject in advance a range of potential options that use the sensibilities and preferences of the subject to potentially guide and aid the subject towards a pre-figured goal of the institutional actor that either naturally emerges or are manufactured in due course.

\footnotetext{
${ }^{171}$ Lukes, Steven. 2005. "Power: A Radical View." In Power: A Radical View, by Steven. Lukes, 14-59. New York: Palgrave Macmillan.
} 
This degree of surveillance coupled with the potential, if not implicit, degree of control conferred upon institutional actors by a society of control, despite the presence of standard freedoms, thereby suggests that it would be reasonable to hold that a leadership democracy under a society of control could be conceived of as being constrained is such a way as to pose a problem for the idea of a charismatic leader being able to overcome the impositions of a society of control since the charismatic leader themselves is a subject with such a society.

\section{How Can the Charismatic Leader Avoid the Impact of the Society of Control?}

If this is now the case, that the presence of a society of control seemingly poses problems for both a charismatic leader and by extension a leadership democracy, the question that is now raised is how one can avoid this outcome? The outcome being a case where the charismatic leader finds themselves to be constrained by the effects of the society of control and by extension the leadership democracy over which they preside is also constrained. Stated more succinctly, granting a society of control, how can Weber's idea of a charismatic leader and a leadership democracy avoid the predicament in which the charismatic leader is unable to operate as a charismatic leader in the proper sense and thus becomes subject to the same impositions as everyone else within a society thereby undermining the special position of charismatic legitimacy?

The answer to this question would seem to lie in the interaction between the institutional mechanisms of the society of control and the manner in which the charismatic leader engages in free actions of one type or another in relation to Weber's conception of power. Weber's conception of power is as follows: “...the probability that one actor within a social relationship will be in a position to carry out his own will despite resistance, regardless of the basis on which the probability rests". ${ }^{172}$ This in turn requires the notion of struggle, where Weber states that "a social relation should be called struggle, if action is pursued with the purpose to impose one's own will against the resistance of a social partner or partners" ${ }^{173}$ In abstract terms, what this constitutes is that the charismatic leader, in the process of engaging in $X$, whatever this may be, engages in a struggle at times to impose their will upon $\mathrm{Y}$.

\footnotetext{
172 Warren, Mark E. 1992. "Max Weber's Nietzschean Conception of Power." History of the Human Sciences 5 (3): 19.

${ }^{173}$ Guzzini, Stefano. 2007. "Max Weber's Power." Re-Reading Weber, or: The Three Fields for the Analysis of Power in International Relations. Turin: Cambridge University Press. 100.
} 
Beginning with the ability of the charismatic leader to engage in $\mathrm{X}$ at time $\mathrm{t}$ in relation to the imposition of their will upon $Y$, whatever $X$ and $Y$ may be, one can argue that despite the charismatic leaders' engagement with $\mathrm{X}$ in relation to $\mathrm{Y}$ for a period of time the mechanisms of control within a society of control do not inherently impinge upon the will of the charismatic leader within the environment over which the bureaucratic political mechanisms of this society preside. Put more succinctly, there is a distinction between the outcome of the charismatic leaders' engagement in $X$ in relation to $Y$ over a period of time and the harvested flows of data that emerge from the rhizomatic assemblages concerning surveillance that constitute the mechanisms of the society of control. The immediate question that arises is how this can be?

In answer to this question, let us begin with the mechanisms of the society of control in relation to the outcomes from engagement with $X$. The mechanisms of the society of control, namely various forms of surveillance over subjects, with the intent on the part of the institutions that utilize such surveillance, of influencing future actions and outcomes, can only in principle interact with the outcome of the subject's engagement with $X$ due to these mechanisms not possessing any means by which the intentionality of the subject (i.e. the Subject's mental states directed towards a certain outcome) can be fundamentally undercut. While it is the case that the mechanisms of the society of control, in the form of various kinds of surveillance, procurement, and management of flows of information can influence the nature of the $X$ that the subject engages with, as is ostensibly the goal, it cannot truly control the engagement itself with $\mathrm{X}$ on the part of the subject if maintenance of the society of control is to be upheld.

Thereby, in the case of the charismatic leader, such a leader is at first able to break through the impositions of the society of control because the mechanisms of the society of control are unable to impinge upon the will of the charismatic leader and are thus unable to impinge upon the manner in which the charismatic leader seeks to impose their will and engage in struggles to do so. Additionally, if for argument's sake the bureaucratic political structures of the society of control sought to control the subject via some kind of physical force then the very nature of the society of control is undermined, since a society of control by its nature functions at a distance from traditional forms of force over the subject. There is a structural distance between the intentionality of the subject and the flows of information that result from engagement with $X$, with the intentionality of the subject existing prior to the existence of $X$ and the creation of information stemming from engagement. 
Returning to the charismatic leader, not only is the charismatic leader not hindered as per the charismatic leader's intentionality, even if the bureaucratic apparatus that the charismatic leader is at the helm of somehow came under the effects of the society of control it is still the case that the charismatic leader themselves is unaffected because the charismatic leader is not constrained via any use of traditional force. It might be objected to that if potentially manufacturing various future instances of $X$ due to the information gathered were successful, that the society of control does in fact exert control over the intentionality of the subject over an extended period of time. However, this can be rebutted if one considers that the intentionality of the subject is still not truly controlled in principle even if the $X$ towards which that intentionality may be directed is wilfully manufactured due to inherent limitations on how a society of control needs to function if it is to be considered as such.

Put more succinctly, the ability of the subject to act freely still exists in principle even in cases where in practice it may be curtailed either via the wilful manufacturing of $X$ or in cases where the subject might truly choose to partake in the manufactured X. And thus, we can say that the subject still possesses the degree of autonomy required to actively choose to do $X$. What this means for the charismatic leader is that even though the charismatic leader emerges from within a society that is subject to the mechanism of the society of control, and comes to power within institutional structures that can seek to utilize the mechanisms of the society of control, it is nevertheless the case that the charismatic leader is able to overcome this purely on the basis that the society of control is unable to impinge upon the will of the charismatic leader and is thus unable to prevent the charismatic leader from exerting that will over whatever the charismatic leader chooses to do.

How is this the case? A threefold answer to this can be proposed if one looks at the position that the charismatic leader comes to hold within a society over time. First, as per Weber, a charismatic leader is set apart from the rest of the population and the limitations of bureaucratic structures by their ability to inspire and gain followers. While the inspiring and gaining of followers does not in itself change the nature of the imposition of the society of control because all subjects involved are embedded within said society and its bureaucratic structures it is nevertheless the case that through this inspiring and gaining of followers that the charismatic leader comes to exist over and above the bureaucratic structures and institutional actors that make up the security assemblages that constitute the mechanisms of the society of control. 
Second, the charismatic leader, by virtue of their deemed charismatic quality is already set apart from the standard person within a society, they possess a set of qualities the standard person does not possess which allows them to inspire and gain followers in the first place. The implication being that there is already a greater distance between a person who comes to be deemed a charismatic leader and the impositions of the society under which that charismatic leader emerges within.

And third, because the mechanisms of the society of control do not impinge upon the freedom of the subject even though it might limit politically relevant freedoms under certain circumstances, the charismatic leader, already set apart from other societal members, is free to pursue the accruing of followers in line with their will that results in the outcome of the charismatic leader gaining control of various bureaucratic structures of society. Through this control of bureaucratic apparatuses, one could observe that because these apparatuses utilize the mechanisms of control in question the charismatic leader overcomes this control by being in a position to direct the manner in which this control is utilized.

However, it could be asked whether even in this case the charismatic leader truly archives such an escape from control given that the charismatic leader is a public servant in the public eye and will thus be intensely surveilled by those over who the charismatic leader presides up to and including institutional actors. This concern can be remedied by considering who would hold power in such circumstances. In such circumstances, even though the charismatic leader is intensely surveilled it is nevertheless the case that it is the charismatic leader that possesses power and not the general public or those working within various institutions. The reasons for this return to what has already been stated about the nature of the charismatic leader. By virtue of the charismatic leader being able to inspire, gain, and keep followers, which in practical terms includes both the general public and those working within institutions, the charismatic leader is not impinged upon by such surveillance on the basis that this surveillance lacks the power of the form wielded by the charismatic leader. The power that this surveillance possesses, if it is to possess any at all in this case, is not able to undermine the capacity of the charismatic leader so long as the charismatic leader is able to continuously inspire and gain followers who will carry out the directions of the charismatic leader and thus the will of the charismatic leader is not impinged upon. 
Subsequently to this threefold answer is the question of the individualised nature of control that the mechanisms of the society of control seek to exert. Through the individualisation of data collection which in turn allows for more nuanced and accurate accounts of the groups to which individuals belong would seem to pose problems for a potential charismatic leader as such specific information could potentially be used to hinder their advance by making it harder to appeal to different groups. However, if one grants that the qualities of the charismatic leader or potential charismatic leader are qualities that others recognise then this individualisation of control would not seem to pose a problem for the charismatic leader in terms of inspiring and gaining followers provided that the control exerted over subjects does not impinge upon those subject's ability to positively perceive certain traits in others.

An additional question to be addressed concerns whether the charismatic leader in any way disrupts the society of control. Given what has already been articulated, the answer to this would tentatively seem to be a yes. Given that the charismatic leader gains control over the bureaucratic political apparatuses within a society that in part go towards the assemblages that make up the society of control it is conceivable that a charismatic leader could determine that the surveillance assemblages that constitute the mechanisms of the society of control be dismantled. A potential impediment to this would be other institutional actors not under the direction of the charismatic leader moving against such an action on the charismatic leader's part, additionally, it is also conceivable that an attempt at manufacturing a withdrawing of popular recognition for the charismatic leader on the part of the wider polity could be attempted by such actors as well which even if unsuccessful would at the very least perhaps slow the charismatic leader in their actions. However, despite the opposition that could potentially emerge, it is nevertheless the case that the charismatic leader in principle has the ability to challenge the society of control due to the position that the charismatic leader holds.

\section{The Role of Intrinsic Properties}

Turning away from the former discussion, let us now look at the case of the subject having an intrinsic property or set of properties $Y$ at a particular time $t$ in relation to the subjects' engagement with $X$. The immediate question that arises is what does it mean for the subject to possess an intrinsic property in this sort of case? Following David Lewis' distinction between intrinsic and extrinsic properties we can note the following: 
"A sentence or statement or proposition that ascribes intrinsic properties to something is entirely about that thing; whereas an ascription of extrinsic properties to something is not entirely about that thing, though it may well be about some larger whole which includes that thing as part." 174

"A thing has its intrinsic properties in virtue of the way that thing itself, and nothing else, is. Not so for extrinsic properties, though a thing may well have these in virtue of the way some larger whole is ..." 175

"If something has an intrinsic property, then so does any perfect duplicate of that thing; whereas duplicates situated in different surroundings will differ in their extrinsic properties." 176

Now, why would one be talking about the nature of linguistic statement here in this context, even in passing, as this would seem to be quite out of place? The answer to which lies in the observation that the nature of intrinsic property needs to be explicated further in order for the full implications of it to be appreciated, and this requires a brief discussion on the nature of linguistic statements as this nature bears upon the manner in which such properties are understood, connected to the external world and by extension how such properties can be deployed. To be more specific, the discussion here requires a linguistic distinction to be made between intrinsic and extrinsic properties and the manner in which a thing, in this case, a subject, possesses them. Thus, we can say that a subject possesses an intrinsic property $Y$ if and only if the linguistic statements about said property truly refer to it, that the subject possesses this property or properties in virtue of its self-contained nature, and the subject possess this property if other subjects can possess the same kind of properties satisfying the same criteria that have been laid out. The implication of this for the charismatic leader being that the charismatic leader's will is something that can be seen as an intrinsic property and thus beyond the control of the mechanisms of the society of control as already stated.

The implication in concrete terms being that if the charismatic leaders' will were not a properly intrinsic property and thus subject to outside control then the ability of the charismatic leader to gain and inspire followers who are then used by the charismatic leader to gain control of bureaucratic structures would be diminished and by extension, the charismatic leaders' ability to overcome the mechanisms of the society of control would be

\footnotetext{
${ }^{174}$ Lewis, David. 1983. "Extrinsic Properties." Philosophical Studies 44: 197.

175 Ibid.

${ }^{176}$ Ibid.
} 
diminished also. Causally speaking, this means that there is no causal mechanism emanating from the mechanisms of the society of control that are able to impose themselves in such a way as to affect the workings of the leader's will precisely because the surrounding environment is unable to remove a quality that a subject possesses in virtue of themselves. No form of surveillance or coercion is capable of affecting the inherent workings of the charismatic leader's will. It might be the case however that such mechanisms, such as surveillance and coercion, could impact on the ability of the leader to express their will externally. Albeit this is not the same as affecting the inherent workings of the leaders' will and it is not immediately clear that such a move would succeed over time. As an imperfect example that nevertheless illustrates the basic point being made here, one might think of the case of Aung San Suu Kyi. As a leader, she was placed under surveillance and house arrest, however, neither of these affected her ability to garner a following over time. The mechanisms of the control were unable to cause a diminishing in the expression of her will over time. Now one could ask questions about whether Aung San Suu Kyi is a charismatic leader in the Weberian sense and whether Myanmar could be viewed as a society of control as opposed to just a disciplinary society but neither question undercuts the basic point being illustrated. By extension, if the charismatic leader directs this will towards the bureaucratic political structures that they preside over it becomes possible for these structures to go break free from the impositions of the society of control.

Focussing for a moment on linguistic statements about $Y$, while it would seem relatively easy for these to be manufactured by the mechanisms of the society of control, ostensibly in a manner similar if not the same as current advertising works now, where linguistic statements propagated via various means of technological communication are used in an attempt to manufacture certain kinds of desires within subjects, certain intrinsic properties, that are to be directed towards certain goals that are themselves created via the same mechanisms within the society of control. Within the context of a leadership democracy this creation of certain kinds of desires, certain intrinsic properties, could be argued to be easily exploitable in the manufacturing legitimacy as it provides a basis from which to prime a subject for accepting various kinds of social, political, and cultural positions presented by bureaucratic political structures. However, the main objection to this, similar to a subject's engagement with $X$, rests on the apparent separateness between a legitimate instance of an intrinsic property $\mathrm{Y}$ arising in relation to the choice to engage in $\mathrm{X}$ and the nature of a created instance of an intrinsic property. In other words, in order for $Y$ to be properly intrinsic to a subject, it would seem to need to arise organically within the mental domain of the subject and not be 
something imposed through the reinforcement of certain psychological cues on the part of the external entity.

An immediate objection that would be raised at this point is that this is exactly what the mechanisms of a society of control would be doing. These would be attempting to impose a certain direction for a subject who would then seemingly form an organic mental response to the psychological cue and thus one could not speak of a subject as possessing truly intrinsic property or properties $Y$ in relation to $X$ because the arising of the mental response would be artificial and not truly organic, thus undercutting the freedom necessary for a leadership democracy within a society of control to overcome the imposition of the society of control. In simple terms, what this means is that a charismatic leader's will to do something needs to arise naturally from their intrinsic intentionality and that an attempt by a society of control to undercut this, in turn, undercuts the degree of freedom needed for both the charismatic leader and the common subject to act in the manner required for the society of control.

\section{The Focus on Pure Theory and the Role of Empirical Examples}

An important point to note at this stage before proceeding further is that what has been presented here is a philosophical argument concerning the relationship between certain kinds of properties and their implications in relation to purely theoretical understandings of political phenomena and are thus do not necessarily need to be evaluated primarily on empirical terms for a few reasons. The idea of a society of control and the idea of a charismatic leader are both ideal types, in other words, abstractions based upon empirical observations. Because both are abstractions, we are able to treat these abstract accounts on their own terms, in other words, we are in a position to analyse only the workings of the theories themselves without necessarily referring to or necessarily applying them to some empirical phenomena, in that we do not necessarily have to draw on anything empirical to make a case for or against a particular position. For instance, we can look purely at whether the theory is internally coherent and whether the conclusion that is argued for follows from the basic premises and granted background assumptions, and we can ask questions about the workings of the one theory if we grant the operation of another as is done here in this thesis. Additionally, there is a seeming difficulty in this case when it comes to empirical examples in that one might question whether or not there are any current regimes that one can satisfactorily say embodies both the society of control and a leadership democracy. Finding examples of charismatic leaders to analyse is not difficult and we can already find reasonably 
good examples of societies of control but finding examples of the two existing simultaneously within a single regime at this point in time is more problematic. Thus, empirical examples may be of potentially limited use as any example one draws on may potentially be able to illustrate the real-world operation of one or the other ideal type but not necessarily both. Because of this, we might not seem to have a straightforward empirical example that could be used to settle the matter of how a society of control and a leadership democracy would interact in the real world.

Nevertheless, given the certain empirical examples that do exist, imperfect as they are, we could arguably come to perhaps a tentative answer as to what these two concepts look like together on an empirical and real-world level. On the question of the society of control, despite Deleuze not saying particularly much about the exact configurations of such a society outside of the broad outline that was covered in the previous section on Deleuze, one could tentatively use as an example of any state that possesses and utilises a significant security assemblage. On this point, one could turn one's attention to the use of surveillance by states such as China or the United States. Both states possess notable security assemblages in the form of intelligence communities which both states willingly utilise for the surveillance of their own populaces in combination with surveillance emanating from more traditional institutions the likes of which Foucault identified whilst also not constraining or enclosing a subject for the purpose of said surveillance. In both cases, the surveillance assemblages that are utilised create and harvest significant flows of information from subjects that can then be utilised for purposes ranging from advertising to internal security. A point of distinction however is that in the case of China the security assemblage is more all-encompassing, in which the creation of things like a social credit system can be conceptualised "as a state surveillance infrastructure" that in part presides over the "data collection, data aggregation, and data analytics" of commercial data created by individual citizens. ${ }^{177}$ Whereas, in the case of the United States, arguably the most powerful elements of the security assemblage are to be found in the form of the United States intelligence community which is preoccupied primarily with security concerns.

Additionally, a state such as China cannot be used to tell us anything notable about a charismatic leader in the Weberian sense due to the specifics of the Chinese political

177 Liang, Fan, Vishnupriya Das, Nadiya Kostyuk, and Muzammil M. Hussain. 2018. "Constructing a Data-Driven Society: China's Social Credit System as a State Surveillance Intrastructure." Policy and Internet 10 (4): 415-453, p. 434. 
system. ${ }^{178}$ A Chinese leader may be charismatic but would come to power on the basis of appointment by the Party and not through the gathering of a wide following who then votes that leader into power. Additionally, due to the specifics of the Chinese political system, the argument could be made with little effort that a leader who rises through the political system would be subject to the mechanisms of the society of control on the basis that Communist Party members are themselves subject to various forms of surveillance and even coercion. In short, while charisma might be a useful thing for a political actor to have, the more important quality, in this case, is political loyalty.

With this in mind, if we limit our focus to the example of the United States, we might tentatively be able to provide an example of both a society of control and a leadership democracy, or at the very least a society of control presided over by a charismatic leader. Here we could perhaps draw upon the example of the Obama administration, in which a charismatic leader comes to be seen as presiding over a state that also possess a significant security assemblage and by extension a society of control. Naturally, this example raises the immediate question of Weber's concept of legal-rational authority and the relationship between a legal-rational political apparatus that puts emphasis on political procedure. However, it is nevertheless enough to note that with the Obama administration we do find an example of a charismatic leader speaking of transcending divides and presenting a vision that was culturally relevant. ${ }^{179}$ If we take up this tentative example, we do not seemingly find a case in which the mechanisms of the society of control impinge upon the will of a charismatic political actor in such a way as to prevent that actor from expressing that will. As will be plainly clear, this example has significant problems notably around whether it makes any sense to treat Obama as a charismatic leader in the Weberian sense and subsequently whether the charismatic authority was in play when he came to power. An argument could easily be made that the Obama administration and Obama's entrance into power represent legal-rational power as opposed to charismatic power despite Obama being a charismatic

\footnotetext{
178 Tian, Chenshan. 2003. "Max weber and China's transition under the new leadership." Journal of Chinese Political Science 8: 27-46.

${ }^{179}$ Bowden, Gary. 2010. "Obama, Palin, and Weber: Charisma and Social Change in the 2008 U.S. Election." Canadian Review of Sociology/Revue canadienne de sociologie 47 (2): 171-190, p.182; Bligh, Michelle C., and Jeffrey C. Kohles. 2009. "The enduring allure of charisma: How Barack Obama won the historic 2008 presidential election." The Leadership Quarterly 20: 483-492; Cetina, Karin Knorr. 2009. "What is a Pipe? Obama and the Sociological Imagination." Theory, Culture \& Society 26 (5): 129-140.
} 
leader. Thus, we arrive back at the problem of whether there are any current or recent regimes that can be seen as being both societies of control and leadership democracies. Arguably, we may conclude at this stage that for the purposes of pure theory this is not particularly pressing. It might be the case that when an empirical political example arises that does reflect both a society of control and the leadership democracy that this example presents evidence against what is being argued in this thesis, but for the time being the concern here shall be purely theoretical.

\section{The Nature of the Charismatic Leader's Capabilities in a Society of Control}

Returning to the previous discussion of properties, the purpose of talking about this is to bring attention to the manner in which a discussion concerning the freedom of a charismatic leader in relation to some coercive force external to said subject entails at the very least a recognition of the role of mental states possessed by the charismatic leader, in that, in order to have proper freedom, a charismatic leader must also have the proper mental states. However, a primary response that can be leveraged against this objection is that while it might very well be the case that the mechanisms of the society of control would perhaps impose a certain direction for the charismatic leader, who would then form a seemingly organic mental response to the psychological cue, the charismatic leader's seemingly organic mental response is in fact not an actually organic response even though it would be a response to a created psychological cues for the purpose of control.

This response rests on the observation that the created psychological cue cannot in and of itself guarantee the desired psychological result on the part of the charismatic leader, it cannot manufacture a truly organic response on the part of the charismatic leader. This would be because of the separation that exists between the nature of the created psychological cue, in the form of some linguistic statement, and the potential interpretative direction of the charismatic leaders' mind which exists independently of the means of control in question. In other words, a society of control cannot guarantee that certain forms of control, such as those seeking to imbue the subject with certain desires, will have the desired outcome over the charismatic leader due to these mechanisms not being able to control the manner in which the charismatic leaders' mind interprets the nature of that which is being used to try and induce said control. To state things more concretely, the mechanisms of control cannot state or propose an intrinsic property or properties $Y$ that are to be taken up by the charismatic leader in a form such that the statement or proposal does not align with something that can 
actually be held to be a potential intrinsic property or properties by the Subject in line with the nature of the charismatic leader.

The next question that arises is the role of time in relation to the charismatic leader's engagement with $\mathrm{X}$ in light of holding $\mathrm{Y}$ property or properties. If it cannot be the case that the mechanisms of the society of control can truly impinge upon the autonomy of the charismatic leader regarding $X$ or impinge upon the holding of intrinsic properties regarding $Y$, then one might ask whether or not it is not possible for the mechanisms of the society of control to influence the trajectory of both via the manipulation of the time in which both of these exist? Put more succinctly, can the society of control exert an indirect influence over $X$ and $\mathrm{Y}$ through the manipulation of the temporal space of the charismatic leader? Now, at this point, it must be reiterated that Deleuze himself did not discuss manipulation itself but rather the effects of certain kinds of technological developments. However, despite this, manipulation is something that can not only be inferred from his discussion but that can also emerge depending on how this technology is used, which is the point here. Now, in order for the charismatic leader to maintain the freedom required for the expression of will discussed here the charismatic leader has to possess an intrinsic property or set of intrinsic properties $Y$ for a period of time in $t$ to $t^{\prime}$ in relation to $X$. How is it, one may ask, that the mechanisms of the society of control could tamper with or intervene in this temporal space?

Such an intervention on the part of the society of control can be advanced by noting how the creation of potential future options towards which to direct the charismatic leader can influence the nature of the subject temporal space and thus change $Y$ in relation to both $t$ and $t^{\prime}$. When the mechanisms of the society of control mine flows of data for relevant information regarding the charismatic leader and then create various options with which to present the charismatic leader at some future time the society of control need only be able to present a multitude of potential options to the subject such that each option requires a slightly different intrinsic property in order to be pursued. Put more concretely the society of control need only present multiple options that each require a different set of desires on the part on the part of the charismatic leader to pursue or present such options continuously such that the subject is presented with different options once the subject is already engaged with one particular option. What this amounts to is the following. It is relevant to note here that society of control itself is an environment and not an actor and thus when it is said that the society of control does something that is meant is that the individual actors that make up the society of control are the ones doing something. When the charismatic leader possesses an intrinsic property 
or set of intrinsic properties in the form of desires $\mathrm{Y}$ which then culminates in that the charismatic leader engaging in $\mathrm{X}$ at time $\mathrm{t}$ for a presumed amount of time that lies between $\mathrm{t}$ and $t^{\prime}$, this period of time between $t^{\prime}$ and $t$ constitutes the temporal space within which the free will of the charismatic leader is manifested in relation to the engagement with an act $X$. Recall that in order for the subject to maintain engagement with $\mathrm{X}$ out of an act of will $\mathrm{Y}$ must remain unchanged for the period of time $t^{\prime}$. However, if the mechanisms of the society of control were to indirectly alter $\mathrm{Y}$ within $\mathrm{t}^{\prime}$ then the autonomy of the charismatic leader can arguably be undermined.

At this point, an objection might be raised as to whether the mechanisms of the society of control are in essence good enough for this kind of operation concerning the constraining of the charismatic leader in the same manner as just another subject. It could be objected to that the information gathered by the mechanisms of the society of control is often ambiguous, incomplete, and subject to competitive pressures and thus is not as useful as it may at first appear. The ambiguity and incompleteness of the data raise an issue for absolutely complete or absolutely clear information given that this can be argued to be a requirement for extrapolation of possibilities, the data only has to be complete to a certain degree and clear enough which is not necessarily possible to achieve merely through the act of waiting and allowing a subject of any description to act. Similarly, competitive pressures are of concern in so far as the primary consideration is the harvesting of produced information by multiple actors who act against each other and thus neutralize each other.

The question that emerges now is that if it is conceivable that in some sense a society of control is able to impinge upon a leadership democracy such that the mechanisms of the society of control are able to intervene between $t$ and $t^{\prime}$ and thus influence the nature of $X$ and $Y$ then how is it that the charismatic leader is able to maintain their freedom in the proper sense such that they can exert their will? Since it would seem that a qualified autonomy seems to emerge where the charismatic leader is properly autonomous on the terms of the society of control, as would ostensibly be the goal. Due to the structural nature of this aspect of control, or attempted control at the very least, it is arguably the case that this is the hardest component of the society of control for the charismatic leader to escape. This is because the charismatic leader has no power over the potential future options that are presented to them by the society of control due to the charismatic leader having no power over the manner in which the data they inadvertently produce is mined by bureaucratic political structures. 
Since there is also a metaphysical or epistemological barrier between the intervention of the society of control at a certain time and the charismatic leader's interaction with that intervention, unlike the $X$ and $Y$, it would seem that there is little ground upon which the charismatic leader could escape this form of imposition unless they were explicitly aware of the intervention on the part of the mechanisms of the society of control being leveraged over the bureaucratic political structures of the leadership democracy, something that would arguably not be the case due to the inability of the charismatic leader to perceive the ways in which the flows of data they have produced has been harvested for data and the way that said data is utilised by other institutional structures and actors in play. However, within the confines of the broad argument advanced here I will posit for now that this inability of the charismatic leader to gain or regain any degree of control in this respect does not fundamentally undercut the argument that the charismatic leader and a leadership democracy is able to overcome the impositions of the society of control.

Subsequently, the charismatic leader through their acts of will can be seen to have a goalseeking behaviour over their own body or mind, in that the charismatic leader has the ability to decide upon a particular course of action in line with their freedom to do so. As is immediately obvious there is a notable overlap in the ability to do $X$ in relation to an intrinsic property or set of properties $\mathrm{Y}$. However, the emphasis here is on the nature of the decision itself, not the ability to decide or the kind of intrinsic property. The set of questions that emerges here is the following, is the decision itself on the part of the charismatic leader under the influence of the mechanisms of the society of control? How could a leadership democracy under such a society use influence over decisions to bolster its power at the expense of the leadership democracy and the charismatic leader? Can the charismatic leader be conceptualised as being free from this influence in any way? Or stated more concretely, do the mechanisms of the society of control shape the decisions and subjectivity of the charismatic leader or not, and can this shaping of subjectivity be used to increase power?

In the case of the decision itself, on first observation, it would certainly seem that it is under the influence of the mechanisms of the society of control. Similar to the manner in which the mechanisms of the society of control can intervene in the temporal space of the charismatic leader engaging in a certain action at a certain time, out of an act of will, it would also seem to be the case that these same mechanisms can intervene in the decision making of the charismatic leader in a similar manner. Decision making is itself a temporal phenomenon in that the charismatic leader makes a certain decision at a certain time in relation to $X$ and $Y$ 
and thus it would seem that the same kind of intervention as that concerning the temporal space of the charismatic leader applies here as well.

Additionally, it would seem to be the case that due to the harvesting of data on the part of the society of control and the multitude of possible future options that are created and can be presented to the charismatic leader that can influence decision making through the provision of certain lines of potential options that can be used to guide the subject down a particular path. In this way is can arguably to be the case that the mechanisms of the society of control exert a direct influence over the decision making of the charismatic leader. The primary objection that can be raised in this respect is that the charismatic leader still has the freedom to engage in a particular action $X$ as outlined previously. In order for the charismatic leader to freely engage in a certain action $\mathrm{X}$, it is a requirement that the charismatic leader first decides to do $X$ in relation to $Y$. Thus, if it can be established that the engagement with $X$ is largely free then it logically follows that the underlying decision to do $X$ is largely free on the basis that nature of the decision itself also functions as a mechanism of the already established freedom of the charismatic leader.

This would hold even in cases where the potential options that are provided to the charismatic leader are pre-determined, in that the charismatic leader can only engage with these pre-determined options freely if the underlying decision itself is free. While this is certainly a qualified notion of autonomy it is nevertheless enough for the purpose of the argument advanced here. Thus, once more it is the case the charismatic leader is not prevented from engaging in an act of will in order to achieve some particular goal, and once more it is the case that mechanisms of the society of control cannot reliably create a future option the likes of which would constrain the charismatic leaders' ability in any notable way.

This all, in turn, raises an interesting question concerning the workings of a leadership democracy under a society of control. Namely, that if it is the case the charismatic leader under a society of control is subject to its influence, namely its particular form of control and discipline, like every other member of society the observation then would seem to follow that those who man the institutions of society and namely that of the leadership democracy are themselves subject to the same mechanisms of control as all other citizenry due to the highly diffuse nature of the power that underlies the society of control. What then are the means via which those that uphold the leadership democracy circumvent these impositions on the part of the society of control? The influence of the society of control being the influence of its 
subtle form of continuous control over subjects procured through flows of data created by those subjects.

More succinctly, the freedom to maintain charisma and legitimacy within a leadership democracy independently of the influence of the mechanisms of the society of control seems to require a degree of true freedom in excess of what said society of control would seem to allow for those within it. Those subject to the society of control and the ends sought by those actors that utilize it are assumedly not only aware of the nature of the society of control but are also seeming holders of a degree of freedom that is not presided over by said society of control.

This oddity can perhaps be dealt with if one utilizes the same conception of political institutions as that of Weber, namely that we should see institutions as not doing anything as such but rather the individuals that man the institutions are the ones that in reality do things and thus animate political institutions into life. Thus, on this account, the control that is exerted from the mechanisms of the society of control is in fact the assertion of the will of a particular societal group over the rest of society via the use of particular institutional mechanisms.

However, since Deleuze's conceptualization of the society of control utilizes the Foucauldian conception of power, those that preside over the society of control and use its mechanisms are themselves subject to the influence of diffuse power in some sense similar to everybody else in a society. This once again raises interesting questions about the agency of those manning the bureaucratic political institutions that constituted the leadership democracy. Namely, if the political actors that man the institutions up to and including the charismatic leaders themselves are also able to maintain their freedom such that they engage in acts of will that result in the control or attempted control of other subjects, is it not the case that a performative contradiction of sorts arises due to the underlying presence of power in which the freedom to act in certain ways towards others in this context negatively impacts the degree of freedom of everyone such that the original degree of freedom required to act in such a manner as in the first case is undermined?

Put more succinctly, due to the Foucauldian conception of power, do the political actors that man the bureaucratic political structures, including the charismatic leader, possess the agency to act in certain ways that attempt to limit the agency of actors outside of the institutions without inadvertently limiting their own agency? Once again it can be argued that the political 
actors manning the institutions do in fact possess this degree of agency precisely because these political actors arguably possess a greater degree of understanding of the functioning of the society of control and because the agency in question is rooted within the functioning of certain institutional arrangements and their maintenance as opposed to being rooted outside of these institutional arrangements, agency happens within the boundaries of power. Additionally, it can be maintained that those manning the institutions possess the degree of agency spoken of here on account of the previously established freedom which does not require a full recognition on the part of the subject to function. In simpler terms, what this amounts to is that if one understands the nature of what impinges upon them then they can take steps to minimize the effects thereof.

The question that now arises is that if what has been outlined here is the case, what is the effect of the society of control over a group of Subjects? Or more specifically do the mechanisms of the society of control affect a group of political actors in ways that are not present merely with individual actors? To answer this question, it would first be necessary to ascertain whether or not the dynamics of a group of political actors influence the ability of each individual actor to perceive the manner in which the mechanisms of the society of control impinge upon them and whether this is in any way problematic. This in turn ties into the question of the establishment of a Subject's freedom and whether their autonomy is in itself something that requires recognition on the part of the political actor to function, does the political actor need to recognize the society of control in order to gain some freedom from it?

To begin, it is conceivable that certain group dynamics might impact on the manner in which political actors engage with the mechanisms of the society of control insofar as those political actors are aware of the manner in which these mechanisms impinge upon them. For instance, let us suppose that a political actor finds themselves part of a group that does not only not perceive the mechanisms of the society of control but does not consider them to exist as such. This group holds that they exist within a society where such mechanisms are not functioning and are thus told that they are freer than what they actually are. In such a case, it is conceivable that an actor might very well come to think in the same manner as the other members of this group and thus become a product of in-group pressures surrounding conformity. However, if we uphold the conception of free acts of volition that has been advanced thus far it would seem that one should conclude that the political actor is still capable of possessing some degree of freedom despite the mechanisms of the society of 
control even though the political actors exist within a group that does not perceive the contours of such mechanisms. This is on the basis that the ability for an actor to engage in $X$, an intrinsic property $\mathrm{Y}$, and the actor must decide, as an act of will, to do $\mathrm{X}$ in relation to $\mathrm{Y}$.

This ability does not seem to be negatively impinged upon by group mechanisms even though such a group might be able to influence not only the options relating to $\mathrm{X}$ but also the nature of the kinds of intrinsic properties $Y$, thus operating in a manner similar to the mechanisms of the society of control albeit on a smaller scale. Thereby, if we grant that an actor is able to maintain the autonomy required to engage in free acts of volition within the confines of a society of control then it seems to follow that said actor is also capable of maintaining the same autonomy within the confines of a group. Moving onto the question of a charismatic leader's recognition of the functioning of the society of control in relation to their autonomy, once more if we grant what has already been outlined concerning the nature of a charismatic leaders' freedom while under the mechanisms of the society of control then it would seem that the charismatic leaders' recognition of said mechanisms is of little relevance.

Indeed, in the process of engaging in free acts of will as has already been outlined it is unlikely that the charismatic leaders would be prevented from imposing their will upon whatever their goal is. This would likewise also be the case if a subject is fully aware of the degree to which the mechanisms of the society of control attempt to exert control over the things with which they engage or whether the thing with which they engage is in fact a product of the society of control. Even if the society of control was not present, the nature of acts usually goes unnoticed by the subject engaging in them. Subjects usually do not take notice of themselves engaging in free acts when they engage in certain actions and usually do not notice where the origin of the intrinsic property that the action takes place in relation to emerges from. Thereby, a subject's knowledge of the influence of the mechanisms of the society of control overall can be argued to not affect the degree of autonomy that has been outlined thus far.

\section{Leadership Democracy under a Society of Control}

So far, the ways in which the mechanisms of the society of control in relation to a charismatic leader and by extension a leadership democracy impinge upon the charismatic leader has been outlined along with the manner in which one can maintain that even though the mechanisms of the society of control seek to control and influence subjects within a society, actors such as a charismatic leader can nevertheless be conceptualized as having more than 
enough freedom for them to engage in free acts of will which in turn lays the basis from which it can be argued that a leadership democracy under a society of control remains largely unaffected by the mechanisms of the society of control even though it may itself seek to use some of these mechanisms. The next component that now must be covered is how this freedom of the charismatic leader translates into and connects with the bureaucratic political institutions of the leadership democracy itself. Namely, the question that now arises is this, if the bureaucratic political structures of the leadership democracy are themselves components of the society of control how can we conceptualize the leadership democracy as not being affected by the society of control?

To begin to provide an answer to this question it is first necessary to note the manner in which a leadership democracy functions and how bureaucratic political structures operate in Weber's thought. And secondly, it is necessary to determine the way in which power functions within a leadership democracy. Concerning the first, Weber's leadership democracy is in its basic form a "charismatic aristocracy" whose democratic institutions were less concerned with matter we now commonly associate with such democratic institutions, such as "rights, equality, justice, or self-rule, than with cultivation of certain character traits befitting a robust national leadership". 180 Such a political configuration for Weber was constituted by a "definite social structure" constituted by three interacting components made up of "lay followers, leaders, and an inner circle" who make up the charismatic aristocracy. ${ }^{181}$ For Weber, this "small group of enthusiastic disciples" possesses a notable importance since for this group "recognition is a duty" that is to be carried out on the basis that they have to consistently "prove their usefulness charismatically". ${ }^{182}$ This charismatic aristocracy is

\footnotetext{
180 Joosse, Paul. 2017. "Max Weber's Disciples: Theorizing the Charismatic Aristocracy." Sociological Theory 35 (4): 335; Kim, Sung Ho. 27. "Max Weber." The Stanford Encyclopedia of Philosophy. November 2017. https://plato.stanford.edu/entries/weber/.

${ }^{181}$ Weber, Max. 1978. "Charisma and its Transformation." In Economy and Society 2, by C. Wittich. G. Roth., 1111-1157. Berkeley: University of California Press; Joosse, Paul. 2017. "Max Weber's Disciples: Theorizing the Charismatic Aristocracy." Sociological Theory 35 (4): 337.

182 Joosse, Paul. 2017. "Max Weber's Disciples: Theorizing the Charismatic Aristocracy." Sociological Theory 35 (4): 337; Weber, Max. 1978. "Three Types of Legitimate Domination." In Economy and Society 1, by G., Wittich C. (ed.) Roth, 212-301. Berkeley: University of California Press; Weber, Max. 1978. "Religious Groups (The Sociology of Religion)." In Economy and Society 1, by G., Wittich, C. (ed.) Roth, 399-634. Berkeley: University of California Press; Weber, Max. 1978. "Charisma and its Transformation." In Economy and Society 2, by C. Wittich. G. Roth., 1111-1157. Berkeley: University of California Press; Weber, Max. 1978. "Political and Hierocratic Domination." In Economy and Society 2, by C. Wittich. G. Roth., 1158-1211. Berkeley: University of California Press; Bendix, Reinhard. 1960. Max Weber: An Intellectual Portrait. New York: Doubleday and Company; Roth, Guenther. 1975. "Socio-Historical Model and Developmental Theory: charismatic Community, Charisma of Reason and Counterculture." American Sociological Association 40 (2): 148-157.
} 
"distinguished from the laity by its propinquity to the leader as a select group of adherents who are united by discipleship and loyalty and chosen according to personal charismatic qualification". 183

Relationally speaking, such charismatic authority can be seen to exist in the relation between the charismatic leader and the small group with whom they surround themselves who in turn have the "ability to comport themselves as exemplary charismatic followers" who are qualified to carry out "charismatic interaction", that form of subservience on the part of the inner group to that the will of the leader ${ }^{184}$ Concerning the role of bureaucracy, Weber held that "modern officialdom" operated in a specific set of ways. ${ }^{185}$ Firstly, "there is the principle of fixed and official jurisdictional areas, which are generally ordered by rules, that is, by laws or administrative regulations" 186 Here routine bureaucratic operations are delegated in a certain way as "official duties", the authority to delegate these duties and give commands relating thereto is governed and distributed in accordance with a set of rules concerning coercive means that may be used, and the fulfillment of these duties are methodically carried out by those who are qualified to do them. ${ }^{187}$

These three combined elements constitute "bureaucratic authority" in the confines of lawful government and "bureaucratic management" in economic matters. ${ }^{188}$ With this understanding, Weber saw bureaucracy as being "fully developed" in political communities only within the confines of the modern state. ${ }^{189}$ In turn, the hierarchical nature of bureaucratic structures creates a "firmly ordered system" of observation in which those higher offices supervise those in lower offices. ${ }^{190}$ This system within bureaucratic structures provides those over whom said structures govern with the ability to appeal "the decision of a lower office to its higher authority" ${ }^{191}$ Additionally, the administration of modern bureaucratic structures is "based upon written documents, which are preserved in their

\footnotetext{
183 Joosse, Paul. 2017. "Max Weber's Disciples: Theorizing the Charismatic Aristocracy." Sociological Theory 35 (4): 337.

${ }^{184}$ Ibid, p.338.

185 Weber, Max. 1991. "Bureaucracy." In From Max Weber: Essays In Sociology, by H.H., Mills, C. Wright. (ed.) Gerth, 196-244. London: Routledge, p. 196.

186 Ibid.

187 Ibid.

188 Ibid.

189 Ibid.

190 Ibid, p. 197.

191 Ibid.
} 
original or draught form" ${ }^{192}$ This creates a section of staff within the bureaucratic structure who take on the role of officials whose job it is to manage the written basis of the bureaucratic structure. ${ }^{193}$ In this vein, it is also the case that within modern bureaucratic structures that these structures require specialized management and that official activity requires the full attention of the official, which takes place in accordance with an established and stable set of rules and procedures. 194

Given the above is necessary to discuss the question of power within a leadership democracy, it has been argued by some that Weber's account of democracy with its emphasis on charismatic leadership is not a form of democracy in any substantial sense as we would ordinarily understand the term on the basis that "it contains no positive account of popular power". 195 Defenders of Weber have argued that the role of charisma is secondary to some "democratic ideal of a self-ruling People", in which charismatic leadership is treated as being universalizable across citizens, or charismatic leaders are seen as arising through democratic procedures such as voting, or even that charismatic leadership is beside the point of Weber's "democratic ethos". ${ }^{196}$ Critics of Weber have argued that Weber's emphasis on charismatic leadership seems to limit the expression of democratic institutions to that of tools for the creation and maintenance of some form of oligarchic rule. ${ }^{197}$

In this case, both defenders and critics have argued that "democratization in terms of the generation of a few select charismatic leaders, in possession of great decision-making authority and radial independence from the electorate "cannot really be a theory of democracy because there would appear to be no meaningful place for the People". ${ }^{198}$ As can be seen from this, the possibility of a leadership democracy under a society of control being affected by the mechanisms of the society of some form of non-democracy seems at first to be a likely outcome despite whatever autonomy a subject may possess since there seems to be little place for the subject to exert any popular power in a meaningful way if at all given the added degree of control over the subject that a society of control would afford. However,

\footnotetext{
192 Ibid.

193 Ibid.

194 Ibid.

195 Green, Jeffrey Edward. 2008. "Max Weber and the Reinvention of Popular Power." Max Weber Studies 8 (2): 194.

196 Ibid.

197 Ibid.

198 Ibid.
} 
by beginning with an alternative account of power we can begin to work a way out of this conundrum.

On this alternative account of power with a leadership democracy, one can begin by stating the leadership democracy does not abandon popular power but rather reinvents it. ${ }^{199}$ On this account, the standard view of power within a leadership democracy only lacks a positive conceptualization of popular power if popular power as a concept "assumes that popular power must refer to an authorial power to self-legislate the norms and conditions of public life, or at least to express substantive opinions, values, and preferences about what kinds of decisions political leaders ought to be making". ${ }^{200}$ Such a standard account of popular power causes issues for Weber's conception of a leadership democracy since a leadership democracy does not make provision for the People to engage in these activities as it refers to the political arena. 201

However, we do possess a set of reasons for holding that this standard notion of political power does not hold in the case of a leadership democracy and that it rather proposes "a preconceived conception of popular power specific to the conditions of modern, mass representative democracy". ${ }^{202}$ To begin, Weber notably drew attention to the particular uniqueness of the moral approach to twentieth-century mass democracy in relation to the former small scale democracies that had arisen in the past in which he held that these older and smaller forms of democracy "have different obligations and therefore other cultural possibilities" ${ }^{203}$ It is likely that Weber thought in this case that some aspect of these new obligations and potentialities would connect with the idea of the leader and a strong nationstate on the global political stage, in which Weber describes leadership democracy as "the palladium of genuine democracy" and "the magna carta of democracy" which propose the idea of the People having some role in the reformulation of political ethics. ${ }^{204}$

Additionally, even if one grants that Weber supported democratic means of governance in procedural terms only as "a means to select leaders with charismatic qualities", this very conceptualization of democratic procedures implies a degree of popular power by its very

\footnotetext{
199 Ibid, p. 195.

200 Ibid.

201 lbid.

202 Ibid.

203 Ibid, p. 216.

204 Ibid, p. 196.
} 
nature. ${ }^{205}$ In other words, if the People were completely inept and unneeded within the confines of politics then there would be little seeming reason for Weber to have lent support to the very institutions that at least in principle would bring the People into the political area. ${ }^{206}$ And finally, it can be argued that the idea that the function of a leadership democracy to bring about a charismatic leader being fundamentally against popular power can be argued to be incorrect on the basis that "the charisma around which Weber orientated his consideration of democracy is not a strictly individual or personal quality" ${ }^{207}$ Rather, it can be argued that there is a relationship between the charismatic leader and the "charismatic community" to whom the leader presents themselves and through whom the leader "is both tested and generated". ${ }^{208}$ This is based on the observation that charismatic authority requires attaining and then maintaining a mass following that "at the very least beholds and receives charismatic individuals" and thus the idea of a charismatic leader existing without a mass behind them is something that is rejected by Weber. ${ }^{209}$

Thus, the requirements of charismatic authority outlined thus far "depends on the recognition by the People or charismatic community" which in turn lays the groundwork for a "norm of popular power implicit in the concept of charisma". ${ }^{210}$ However, articulating the exact nature of this power runs into Weber's insistence concerning the distinction between formal and fictive notions of popular support concerning the charismatic leader, in which the People do not choose the leader as such but rather have a duty or recognize the charismatic leader as being suitable to lead. ${ }^{211}$ Thus, in the instance of a modern leadership democracy, such as one possibly under a society of control as is discussed in this thesis, "the People's recognition, even though now constative and not just reflective of the leader's charismatic authority, is likewise not an autonomous choice" due to the conditions by which their support attained. 212 However, the "recognition which the charismatic community bestows upon the charismatic leader" does not only manifest in overt displays of support but rather also through the passive receptivity of the audience in question. ${ }^{213}$ Within this passive receptivity and recognition, one can find not only the recognition "that is most constitutive of the

\footnotetext{
205 Ibid.

206 Ibid.

207 Ibid, p. 197.

208 Ibid.

209 Ibid.

${ }^{210} \mathrm{Ibid}$.

${ }^{211}$ Ibid.

212 Ibid, p. 198.

213 lbid.
} 
charismatic authority of the leader" but also the crucial way in which the People exert power over the leader. ${ }^{214}$

Thus, while it is not a requirement that a charismatic figure must do what the People want it is necessary for the People to confer popular recognition and it is a requirement that the charismatic authority is subject to the scrutiny of the People. ${ }^{215}$ As a whole then the combined observation that Weber at times presented an idealized notion of mass democracy, lent support to "political institutions that would bring the People into politics", along with his conceptualization of the charisma in which popular power is "modelled on the ocular power of the charismatic community", leads one to conclude that only a particular formulation of political power is being rejected in favour of an alternative account of popular power. ${ }^{216}$ Once more, the purpose of this discussion here is to outline the manner in which a leadership democracy functions and how bureaucratic political structures operate so that one can come to an accurate understanding of how a leadership democracy and a society of control can be conceptualised to interact.

We can now return to the question of if the bureaucratic political structures of the leadership democracy are themselves components of the society of control how can we conceptualize the leadership democracy as overcoming the effects of said society of control? As has already been articulated bureaucratic structures possess a particular form of hierarchical operation, the leadership democracy can be conceptualized as possessing a certain kind of popular power centred around the need for popular recognition and thus recognition on the part of subjects along with possessing the standard set of democratic institutions, and the charismatic leader being able to be conceptualized as having the autonomy necessary for the free acts of will. From here one can build an argument in the following form: Despite the mechanisms of the society of control mining the data of subjects for information within a society with the purpose of extending control from a closed to an open domain that can potentially be used to try and shape possible future outcomes of the subjects in relation to the will of the institutional actor utilizing said mechanisms, the leadership democracy still maintains not only the procedural elements of democratic regimes in which it has to maintain the popular recognition of the subjects, who are free to express their will, over which the

\footnotetext{
${ }^{214}$ Ibid.

215 Ibid.

${ }^{216}$ Ibid, p. 199.
} 
leadership democracy presides but also that the charismatic leader is unhindered in expressing their will as already articulated previously. Thus, the leadership democracy within a society of control can be argued to overcome the impositions of a society of control in which both the subjects within a society and the charismatic leader become unconstrained. In concrete terms, this can be argued on the basis that mechanisms of the society of control first cannot impinge upon the free action of subjects within a society if a society of control is to retain its nature as a society of control and, second, cannot impinge upon the charismatic leader primarily because it cannot prevent the charismatic leader from inspiring and gaining followers that the charismatic leader then uses as a means to come into a position of power over the bureaucratic apparatuses that in part make up the surveillance assemblage that contributes to the society of control.

Moving onto the procedural elements of the leadership democracy, even though it has already been established previously that the mechanisms of the society of control can exert a degree of control over the subject that is at the very least very difficult for the subject to overcome this component this does not pose an issue. As has been already articulated this kind of influence on the part of bureaucratic political structures in terms of trying to influence a subject to vote in a certain manner is relatively standard across regimes that possess such procedural apparatuses. Now, if it is the case that the charismatic leader at the head of the leadership democracy requires the popular recognition of the People, who are a collection of subjects, then it follows based on what has been laid out previously that these objects would be engaging in this popular recognition out a free act of will and thereby these subjects have the ability to change the direction of their popular recognition as does the charismatic leader.

It may be objected to immediately that if the mechanisms of the society of control impinge upon the subject most strongly on the point of directing the subject's voting preferences in order to direct these preferences towards whomever the charismatic political actors are at the time and that charismatic actors can be manufactured in order to appeal to disparate groups then it would seem to be the case that what has just been stated concerning popular recognition cannot be, as this would seem to be the most important function of the mechanisms in question for any political institution wielding them. However, if one considers the point that the impinging of the society of control in this particular case does not diminish the manner in which the subject can nevertheless be considered to possess the autonomy required to engage in free acts of will in the areas outside of this specific instance of voting preferences then it can be argued that popular recognition is something that rests outside of 
the specific instance of voting preferences and this exists within the domain in which the subject possesses said level of freedom, all of which applies to the charismatic leader as well.

Where and how would this popular recognition exist? It can be argued that popular recognition exists as an $\mathrm{X}$ in relation to an intrinsic set of property or set of properties $\mathrm{Y}$ at a certain time t towards with which subjects engage. And thus, the same arguments concerning the manner in which the mechanisms of the society of control do not impinge upon the freedom of the subject's engagement with $X$ apply, with the only difference being that $X$ has now been defined. But more substantially, in order for the mechanisms of the society of control to be considered able to manufacture popular recognition, it would be necessary for said mechanisms to be able to influence subjects in such a way that the subjects perceive the particular charismatic political actor as fulfilling the basic expectations of the subject. This would seemingly be quite difficult for such mechanisms as these mechanisms cannot manipulate something that in some sense rests outside of an engagement with a certain thing $X$ in accordance with an intrinsic property or set of properties.

Put another way, the mechanisms of the society of control cannot guarantee that subjects will engage in popular recognition of the charismatic leader due to such recognition in and of itself lying outside of the parameters of both $\mathrm{X}$ and $\mathrm{Y}$. A subject can be forced to or at the very least guided down a certain path, however, the subject cannot be forced to either agree with or approve of the things that they are being forced or guided to do. Thereby if it is the case that popular recognition is not something that can be controlled by the mechanisms of the society of control then by extension the political bureaucratic structures and the charismatic leader of the leadership democracy do not have control of popular recognition either and by extension their freedom to will something is not imposed upon either.

This in turn lays the basis for a leadership democracy under a society of control not preventing either the charismatic leader or a leadership democracy from overcoming its impositions on the basis that if the popular recognition cannot be controlled by those utilizing the mechanisms of the society of control then the electoral procedures concerning candidates cannot be controlled without the risk of opposition from the populace which in turn has the capability of threatening the stability of the leadership democracy overall. If for instance a charismatic leader at the helm of political bureaucratic structures within a society of control, or any other institutional actor, attempted to use the mechanisms of the society of control to sway the voting subject away from voting for a certain candidate, something a charismatic 
leader or charismatic political actor may try to achieve based on what has already been outlined, the charismatic leader or charismatic candidate cannot ensure from this action that the voting subject will extend popular recognition to them and in turn they run the risk of the voting subject removing said popular recognition, at which the political unrest can potentially emerge.

While such attempts at such manipulation take place within democratic regimes ordinarily, the point of departure here concerns the specific use of the mechanisms of the society of control. In concrete terms, this requires a return to the concept of the surveillance assemblage already spoken about. In practice within the context just outlined, this would constitute the charismatic leader, political institutions, the State writ large, and so on utilizing diffuse forms of surveillance as the means to overtly manipulate the political preferences of voters so that the charismatic leader, political institution, or the State can maintain power and a certain status quo. However, given the nature of surveillance assemblages and the way they function as a mechanism within the society of control such overt displays of attempted coercion on the part of political actors does is unlikely to succeed. Firstly, because the voters in question would likely push back against such attempts at coercion and in the process of doing so withdraw popular recognition from the political actors in question. Secondly, such attempts at coercion are no longer in keeping with the basic principle of the society of control, namely the use of free actions as a means of control which is undermined by overt displays of coercion.

An immediate objection can be raised to such a suggestion that due to the nature of how the mechanisms of the society of control can be wielded by a given political actor that the opposition could be a controlled opposition or that it lacks power. However, such an objection can be rebutted on the basis of the relationship between the extension of popular recognition on the part of subjects and the charismatic leader over which this recognition is being extended. For instance, if it were the case that the opposition was merely a controlled opposition where even if the voting subject were to vote for this potential charismatic leader this potential leader would merely echo the current charismatic leader once in power, then the voting subject is still in the position of being able to retract popular recognition of this charismatic leader. And if it were the case that the opposition was merely powerless in the face of the current charismatic leader regardless of whether the opposition was in power or not then something similar emerges, the voting subject is still in the position of being able to 
retract popular recognition of this charismatic leader and continued to do so until a charismatic leader is presented to whom the voting subject sees fit to extend said recognition.

Thereby, while the mechanisms of the society of control can technically be used to guide or force the voting subject in a particular direction towards a particular charismatic leader, if this is done in a case where an oppositional and charismatic leader is rendered either subservient or powerless relating to the very mechanism that allows for the voting subject to be guided or forced in this direction, this can backfire against the leadership democracy due to the potential for popular recognition to be withdrawn. Let us now move onto the substantive element of a leadership democracy, namely that in order for the popular recognition to be maintained there has to be a legitimate representation of People by the charismatic leader. Though, as has already been outlined, the mechanisms of the society of control might be used by a particular political actor specifically to try and exert control over the preferences of the subject as far as is possible and contribute to the manufacturing of perceived charismatic leaders that are to be used in order to appeal to the varying preferences held by varying subjects within a polity and thereby it would seem that legitimate representation is something that can to be manufactured and thus controlled.

However, as has also already been outlined, not only does the subject still possess the freedom required for free acts of will it is still the case that standard freedom that would be expected under a leadership democracy as such are maintained in order to provide the environment necessary for these freedoms and it is here that legitimate representation on the part of the charismatic leader lies. Thereby, it becomes necessary for the charismatic leader to maintain the structural environment in which the freedom of the subject can be expressed. Given that the subject existing or at the very least perceive themselves to exist in a society in which such freedoms exist or seem to exist, such subjects on average do not want to see their freedoms or perceived freedoms diminished and thus will seek to have them protected via those in elected office with the expectation that those in said elected offices are going to adhere to their obligation to uphold the state of said freedoms or perceived freedoms. Thus, it becomes incumbent upon the potential charismatic leader to uphold the expectations of those who voted for them in popular recognition is to be maintained on the part of the People. Additionally, it becomes incumbent upon the charismatic leader to maintain these freedoms or at the very least seeming freedoms on the basis that it is precisely because these freedoms are left untouched that the society of control can function at all. Thus, it is on the basis laid out here that it can be maintained that a charismatic leader and a 
leadership democracy under a society of control are not constrained by or imposed upon the mechanisms of the society of control precisely because such mechanisms are unable to constrain both the will of the charismatic leader and the will of the subjects over whom the charismatic leader presides.

It is also pertinent to mention some of the implications that have not been spoken about in this section and thesis in general due to space constraints. The first is the impact of the society of control on the structures of rationalisation and the relationship to surveillance capitalism. It may arguably be the case that the society of control can be conceptualised as furthering rationalisation through the use of surveillance capitalism. Deleuze's discussion of the operation of capitalist market forces as a tool of social control could be taken as a basis from which to argue that the logic of the capitalist market combined with the dissolution of enclosure constitutes the expansion of a certain form of rationalisation in which the underlying logic of the market increasingly seeps ever further into the lives of individual subjects. The second is whether the mechanisms of the society of control either possess or develop their own legitimacy. Here, given that the mechanisms of the society of control exist in a way such that they are not generally seen to be immediately imposing upon a subject, it might be argued that this question is not immediately relevant to the question of legitimacy. Tentatively speaking, in a case where such mechanisms might impose upon a subject, it would seem on a cursory glance that whether or not such mechanisms are seen as legitimate on the part of individual actors will depend upon the specifics of the case in question. Related thereto, the third is whether charismatic authority, apart from a leadership democracy, can overcome the legitimacy that mechanisms of the society of control may have. The answer to this, at this stage, might tentatively be argued to be a yes. Assuming that there is a prevailing case in which the legitimacy of the mechanisms of the society of control are in question and it is generally agreed that they are legitimate and granting that a charismatic leader is able to overcome the mechanisms of the society of control within the context of a leadership democracy one might conclude that a charismatic leader is capable of the same things outside of the context of a leadership democracy. But once again, there is not enough space to explore these elements further here, however one should keep them in mind when thinking about the interaction between these two thinkers. 


\section{Concluding Remarks}

In this thesis, it has been argued that a leadership democracy under the guidance of a charismatic leader is capable of overcoming the impositions of a society of control. This thesis began by providing a summary of both Weber's and Deleuze's thought as it concerns the ideas of leadership democracy and the society of control, respectively. For Weber, leadership democracy was outlined within the wider surrounding context of his thought as it relates to legitimacy, charisma, and political power structures, all of which impinge upon and go towards determining the nature of a leadership democracy and the charismatic leader. For Deleuze, the idea of the society of control as outlined in relation to the work of Foucault as it relates to the concept of control within a society, in so doing it was outlined how the society of control exits as a development upon the concept of the Disciplinary Society. Additionally, it was outlined how the society of control operates through the use of security assemblages and how these assemblages seek to exert control through the use of information gathered from a subject going about their lives in an otherwise free manner.

Concerning the argument itself, it was first argued that despite the presence and imposition of a society of control that a charismatic leader at the helm of a leadership democracy can breakthrough and overcome the mechanisms of a society of control because the society of control is unable to prevent the charismatic leader from inspiring and gaining followers that allow for the charismatic leader to rise to a position of control over the bureaucratic apparatuses that go towards making up the security assemblages within a society of control. In so doing, three sections were used. The first covered the relationship between a charismatic leader, leadership democracy, and the society of control where it presented a case for how a society of control could be argued to lead to an imposition upon both the charismatic leader and leadership democracy such that both are constrained. The second covered the ways in which the conclusion of the former section can be circumvented where a case was presented for why one should not see the presence of the society of control as being an imposition upon a charismatic leader's autonomy such that the charismatic leader loses the degree of freedom needed for them to overcome and break through the society of control. And the third covered the way in which this continued presence of a charismatic leader's freedom can translate over into the wider socio-political institutions.

Given what has just been argued within this thesis, the immediate question is; what now? Where does this leave this one and what is the next step as it concerns theorizing on this given 
topic? In brief, it has been argued that the presence of a society of control, which uses a subject's free actions for purposes of control, does not affect either a charismatic leader at the helm of political apparatuses or a leadership democracy which are both capable of, through the charismatic leader, of overcoming the impositions of a society of control. To begin, we can think about the immediate limitation of the thesis and what has not been said therein. The question of the relationship between free will and theoretical accounts of political phenomena stands out as a notable case. If it is not the case that the differences in theoretical accounts of free will and volition have an effect on theoretical accounts of political phenomena, then it is safe to assume that the entire premise of the thesis collapses in on itself. While it has been assumed to a certain degree within the confines of this thesis that it is indeed the case that such an effect between the former and the latter is present, indeed it could be argued that showing such a connection has been a secondary feature of this thesis, it is still the case that more work would have to be done on this specific topic in order to extend it out into a properly robust theorization. Indeed, such a task would seem to constitute a work or a set of works the length of a thesis in its own right in order for justice to be done to this particular topic. Nevertheless, the assumption that has been used here in this thesis ought to suffice for all practical purposes within this context.

Additionally, such questioning of the relationship between free will and theoretical accounts of political phenomena, or at the very least social phenomena, would also seem on first reading to undercut Deleuze's theory of the society of control. This would be largely due to the observation that the theory rests upon a degree of interaction between the engagement with one's free will and the use of this engagement by an outside actor for this actor's own benefit. Likewise, to the case presented above, if this is not so then it is safe to assume that the entire premise of the thesis would once again collapse in on itself. And likewise, once more to the previous case, it is still the case that more work would have to be done on this specific topic in order to extend it out into a properly robust theorization that would also constitute a work or a set of works the length of a thesis in its own right in order for justice to be done to this particular topic. But once more, the assumption used here in this thesis ought to suffice for all practical purposes within this context. Subsequently, the idea of the society of control was theorized as a phenomenon that would take place within the confines of capitalism, in part aiding to bring about surveillance capitalism. The immediate theoretical question that emerges from this is whether the concept of the Society of Control is relegated only to the confines of capitalism or whether it could in principle operate or emerge within non-capitalist contexts, once more this is a question to be answered at another time. 
Concerning Weber things are just as interesting. Within the literature that has been utilized in this thesis, one might notice relatively quickly the degree of interpretation is in play. Indeed, within the secondary literature there is much in the way of interpretation concerning the exact implications of a leadership democracy, ranging from an inherent lean towards nondemocracy to an inherent lean, if otherwise slightly idiosyncratic by comparison to the usual forms of representative democracy we are usually familiar with in practice, towards proper democracy. Given these varying interpretations, which are based often on the interpretive weight of certain passages within the primary texts over others, it is more than conceivable that one could object to the claim of this thesis on this basis alone. Such objections may range from arguing that the presence of the society of control is irrelevant due to the already present non-democratic lean, to arguing that because liberal freedoms are still largely intact, if albeit slightly curbed in terms of their full articulation, that the lean towards proper democracy is not diminished in any meaningful way. Both of these forms of objection could raise interesting counterpoints to the claim of this thesis but would, like the previous topics, require their own works in order to be expanded upon.

However, these limitations and potential objections aside, the thesis does present one with an expansion upon theorizing within both Weberian and Deleuzian frameworks. On the one hand, it pairs aspects of Weber's work with elements of theory one would not seem to ordinarily find paired with his work, and on the other, it pairs Deleuze's work with theory that is located closer to the mainstream in terms of theorizing about representative democracy. Such theorizing can certainly be taken further, and ostensibly this would be the next step for this topic in which the finer details of the argument laid out here are explicated in even more detail and in which the aforementioned areas and objections will be dealt with more concretely. This would seem to be the path forward. 


\section{Works Cited}

Beetham, David. 1989. "Max Weber and the Liberal Political Tradition." European Journal of Sociology 30: 311-323.

Bellamy, Richard. 1992. Liberalism and Modern Society. University Park: Pennsylvania State University.

Bendix, Reinhard. 1960. Max Weber: An Intellectual Portrait. New York: Doubleday and Company.

Bligh, Michelle C., and Jeffrey C. Kohles. 2009. "The enduring allure of charisma: How Barack Obama won the historic 2008 presidential election." The Leadership Quarterly 20: 483-492.

Bowden, Gary. 2010. "Obama, Palin, and Weber: Charisma and Social Change in the 2008 U.S. Election." Canadian Review of Sociology/Revue canadienne de sociologie 47 (2): 171-190.

Cetina, Karin Knorr. 2009. "What is a Pipe? Obama and the Sociological Imagination." Theory, Culture \& Society 26 (5): 129-140.

Deleuze, Gilles, and Felix. Guattari. 1987. A Thousand Plateaus. Minniapolis: University of Minnesota Press.

Deleuze, Gilles. 1992. "Postscripts on the Society of Control." October 59: 3-7.

Foucault, Michel. 1975. Surveiller et punir. Paris: Gallimard.

Galič, Maša, Tjerk Timan, and Bert-Jaap. Koops. 2017. "Bentham, Deleuze and Beyond: An Overview of Surveillance Theories from the Panopticon." Philosophy \& Technology 30: 9-37.

Glassman, Ronald M. 1984. "Manufactured Charisma and Legitimacy." In Max Weber's Political Sociology: A Pessimistic Vision of a Rationalized World, by Ronald M., Murvar, Vatro. (ed.) Glassman, 217-235. Westport: Greenwood Press.

Green, Jeffrey Edward. 2008. "Max Weber and the Reinvention of Popular Power." Max Weber Studies 8 (2): 187-224.

Gutting, Gary and Oksala, Johanna. 2018. "Michel Foucault." The Stanford Encyclopedia of Philosophy. 22 May. Accessed July 13, 2020. https://plato.stanford.edu/entries/foucault/.

Guzzini, Stefano. 2007. "Max Weber's Power." Re-Reading Weber, or: The Three Fields for the Analysis of Power in International Relations. Turin: Cambridge University Press. 97-118.

Haggerty, Kevin D, and Richard V. Ericson. 2000. "The surveillant assemblage." British Journal of Sociology 51 (4): 605-622.

Joosse, Paul. 2017. "Max Weber's Disciples: Theorizing the Charismatic Aristocracy." Sociological Theory 35 (4): 334-358.

Kim, Sung Ho. 27. "Max Weber." The Stanford Encyclopedia of Philosophy. 2017 November. https://plato.stanford.edu/entries/weber/.

Kim, Sung Ho. 2007. "Liberalism, Nationalism, and Civil Society." In Max Weber's Politics of Civil Society, by Sung Ho. Kim, 133-172. Cambridge: Cambridge University Press.

Kim, Sung Ho. 2002. "Max Weber and Civil Society: An Introduction to Max Weber on Voluntary Associational Life (Vereinswesen)." Max Weber Studies 2 (2): 186-98.

Krivý, Maroš. 2018. "Towards a critique of cybernetic urbanism: The smart city and the society of control." Planning Theory 17 (1): 8-30. 
Lazzarato, Maurizio. 2006. "The Concepts of Life and the Living in the Societies of Control." In Deleuze and the Social, by Martin Fuglsang and Bent Meier. Sørensen, 171-190. Edinburgh: Edinburgh University Press.

Lewis, David. 1983. “Extrinsic Properties.” Philosophical Studies 44: 197-200.

Liang, Fan, Vishnupriya Das, Nadiya Kostyuk, and Muzammil M. Hussain. 2018. "Constructing a DataDriven Society: China's Social Credit System as a State Surveillance Infrastructure." Policy and Internet 10 (4): 415-453.

Lukes, Steven. 2005. "Power: A Radical View." In Power: A Radical View, by Steven. Lukes, 14-59. New York: Palgrave Macmillan.

Márquez, Xavier. 2018. “Max Weber's Charismatic Democracy." In Democratic Moments: Reading Democratic Texts, by Xavier. Márquez, 145-152. London: Bloomsbury Academic.

Márquez, Xavier. 2016. "The Irrelevance of Legitimacy." Political Studies 64 (1): 19-34.

Mommsen, Wolfgang J. 1974. "A Powerful Nation State as Weber's Political Ideal." In Max Weber and German Politics 1890-1920, by Wolfgang J. Mommsen, 35-67. London: University of Chicago Press.

Patton, P. 1994. "MetamorphoLogic: Bodies and Power in A Thousand Plateaus." Journal of the British Society of Phenomenology 25 (2): 157-169.

Roth, Guenther. 1975. "Socio-Historical Model and Developmental Theory: charismatic Community, Charisma of Reason and Counterculture." American Sociological Association 40 (2): 148-157.

Satkunanandan, Shalini. 2014. "Max Weber and the Ethos of Politics beyond Calculation." American Political Science Review 108 (1): 169-181.

Schroeder, Ralph. 1998. Max Weber, Democracy, and Modernization. London: Palgrave Macmillan.

Thornton, Patricia M. 2010. "Censorship and surveillance in Chinese cyberspace: Beyond the Great Firewall." In Chinese Politics : State, Society and the Market, by Peter Gries and Stanley (eds) Rosen, 179-198. Milton Park: Taylor \& Francis Group.

Tian, Chenshan. 2003. "Max Weber and China's transition under the new leadership." Journal of Chinese Political Science 8: 27-46.

Warren, Mark E. 1992. "Max Weber's Nietzschean Conception of Power." History of the Human Sciences 5 (3): 19-37.

Weber, Max. 1978. "Bureaucracy." In Economy and Society 2, by C. Roth, G. Wittich, 956-1005. Berkeley: Berkeley University Press.

Weber, Max. 1991. "Bureaucracy." In From Max Weber: Essays In Sociology, by H.H., Mills, C. Wright. (ed.) Gerth, 196-244. London: Routledge.

Weber, Max. 1978. "Charisma and its Transformation." In Economy and Society 2, by C. Wittich. G. Roth., 1111-1157. Berkeley: University of California Press.

Weber, Max. 1978. "Domination and Legitimacy." In Economy and Society 2, by G. Roth and C. Wittich, 941-955. Berkeley: University of California Press.

Weber, Max. 1978. "Political and Hierocratic Domination." In Economy and Society 2, by C. Wittich. G. Roth., 1158-1211. Berkeley: University of California Press.

Weber, Max. 1978. "Religious Groups (The Sociology of Religion)." In Economy and Society 1, by G., Wittich, C. (ed.) Roth, 399-634. Berkeley: University of California Press.

-. 1975. Roscher and Knies: The Logical Problems of Historical Economics. New York: The Free Press. 
Weber, Max. 1991. "Science as Vocation." In From Max Weber: Essays In Sociology, by H.H., Mills, C. Wright. Gerth, 129-156. London: Routledge.

Weber, Max. 1991. "Structures of Power." In From Max Weber: Essays in Sociology, by H.H., Mills, C. Right. Gerth, 159-179. London: Routledge.

-. 1949. The Methodology of the Social Sciences. Chicago: The Free Press.

Weber, Max. 1994. "The Nation State and Economic Policy." In Weber: Political Writings, by Lassman, Peter; Spiers, Ronald., 1-28. Cambridge: Cambridge University Press.

Weber, Max. 1978. "The Occidental City." In Economy and Society 2, by C. Wittich. G. Roth., 12361265. Berkeley: University of California Press.

Weber, Max. 1978. "The Plebian City." In Economy and Society 2, by C. Wittich. G. Roth., 1301-1339. Berkeley: University of California Press.

Weber, Max. 1994. "The Profession and Vocation of Politics." In Weber: Political Writings, by Lassman, Peter; Speirs, Ronald., 309-369. Cambridge: Cambridge University Press.

Weber, Max. 1978. "Three Types of Legitimate Domination." In Economy and Society 1, by G., Wittich C. (ed.) Roth, 212-301. Berkeley: University of California Press.

Weber, Max. 1994. "Three Types of Legitimate Domination." In Economy and Society 1, by C (ed.) Wittich and G. Roth, 212-301. Berkeley: University of California Press. 